\title{
Debata „Praca i dialog społeczny w Polsce” - problem integracji świata pracy i świata nauki
}

Inicjatywa związana z międzynarodową konferencją naukową „Społeczne granice pracy" / Social Boundaries of Work (skrótowa relacja $z$ debaty i towarzyszącej jej dyskusji)

\section{Moderator:}

Sławomira Kamińska-Berezowska (Uniwersytet Śląski w Katowicach)

Asystent moderatora:

Bartosz Mika (Uniwersytet Gdański)

Prelegenci:

Jan Guz (Ogólnopolskie Porozumienie Związków Zawodowych)

Kazimierz Siciński (NSZZ „Solidarność”)

Aneta Trojanowska (Związek Nauczycielstwa Polskiego)

Sławomir Wittkowicz (Forum Związków Zawodowych)

Głosy w dyskusji:

Krzysztof Jasiecki (Uniwersytet Warszawski)

Julia Kubisa (Uniwersytet Warszawski)

Agnieszka Mińkowska (NSZZ „Solidarność”)

Adam Mrozowicki (Uniwersytet Wrocławski)

Barbara Surdykowska (Biuro Ekspertów Komisja Krajowa NSZZ „Solidarność”) 


\section{Sławomira Kamińska-Berezowska:}

W ramach cyklu konferencji naukowych „Społeczne granice pracy” w tym roku po raz pierwszy zdecydowaliśmy się zainicjować debatę „Praca i dialog społeczny w Polsce" w celu budowania płaszczyzn spotkań praktyków i teoretyków, świata pracy i świata nauki. Zależy nam na budowaniu takiej solidarności przez małe „s”, takiego solidaryzmu społecznego dla budowania społecznej gospodarki rynkowej przyjaznej wszystkim uczestnikom rynku. O tej solidarności różnych aktorów życia społecznego mówił też profesor David Ost w trakcie pobytu latem w Polsce na różnych wykładach, a zatem mam nadzieję, że i w tym wypadku będziemy mogli liczyć na jego komentarz. Wyzwaniem dla nas jest pytanie, w jaki sposób pogłębiać integrację przedstawicieli świata pracy i badaczy socjologów, bo dotąd jedną z utrwalonych aktywności działań socjologów jest ich praca jako specjalistów do spraw zarządzania personelem, ale niestety samą koncepcję zarządzania personelem (czy zarządzania zasobami ludzkimi - human resources management) można uznać za filozofię biznesu służącą w swej skrajnej wersji tylko interesom pracodawców, a nie pracobiorców, czyli w tym zakresie także rola socjologów pracy wymaga pewnej modyfikacji. W tym sensie socjolodzy czy absolwenci socjologii zatrudnieni w działach ZZL (czy HR) reprezentują tylko jedną stronę stosunków pracy - $\mathrm{i}$ to jest strona pracodawców, co jest niesymetryczne i warto ten stan rzeczy zmienić.

Początkowo myśleliśmy, aby na naszą debatę zaprosić także przedstawicieli pracodawców, ale właśnie ze względu na występującą w Polsce niesymetryczność dyskursu (i studiów akademickich) w zakresie zarządzania zasobami ludzkimi zdecydowaliśmy się na debatę tylko ze stroną społeczną, z przedstawicielami organizacji związkowych.

W każdym razie jako organizatorzy debaty bardzo cieszymy się, że udział w niej zaaprobowali liderzy trzech reprezentatywnych związków zawodowych, którzy zgodzili się zabrać w niej głos w kolejności alfabetycznej. Niestety, ze względu na sytuację w ochronie zdrowia Pani Dorota Gardias, przewodnicząca Forum Związków Zawodowych, w ostatniej chwili musiała odwołać swój przyjazd, ale wskazała godnego zastępcę - Pana Sławomira Wittkowicza, przewodniczącego Branży Oświaty i Nauki Forum Związków Zawodowych, a także przewodniczącego Wolnego Związku Zawodowego „Solidarność-Oświata”. Trzeba zauważyć jednak, że Pan Sławomir Wittkowicz ma nazwisko zaczynające się na literę „W”, a zatem będzie zabierał głos w dalszej kolejności.

Ostatecznie zatem kolejność zabierania głosów jest następująca:

- Pan Jan Guz - przewodniczący Ogólnopolskiego Porozumienia Związków Zawodowych,

- Pan Kazimierz Siciński - przewodniczący Regionalnej Sekcji Nauki NSZZ „Solidarność",

- Pani Aneta Trojanowska - prezes Rady Uczelnianej Związku Nauczycielstwa Polskiego przy Uniwersytecie Śląskim w Katowicach,

- Pan Slawomir Wittkowicz - przewodniczący Branży Oświaty i Nauki Forum Związków Zawodowych. 
Pragnę wyjaśnić, że brak obecności Pana Piotra Dudy, przewodniczącego NSZZ „Solidarność”, jest związany z innymi jego obowiązkami służbowymi, a zastępować go miał Pan Dominik Kolorz, czyli przewodniczący Zarządu Regionu Śląsko-Dą̧browskiego NSZZ „Solidarność”, który niestety w ostatniej chwili ze względów zdrowotnych udział w debacie musiał odwołać, ale życzył owocnej dyskusji, a także wyraził nadzieję, że Pan Kazimierz Siciński, przewodniczący Regionalnej Sekcji Nauki NSZZ „Solidarność”, w jakimś stopniu jego czasową niedyspozycję zrekompensuje.

Planując naszą dyskusję zdecydowaliśmy się ją skoncentrować na takim przejściu od spraw ogólnych do bardziej szczegółowych, a także na zadaniu dość ogólnych pytań zaproszonym liderom. To ze względu na presję czasu i na zapewnienie czasu do ogólnej dyskusji, skoncentrowanej, mam nadzieję, na kwestii współpracy świata pracy i świata nauki, badaczy. W zakresie technicznym długości wypowiedzi będzie pilnował moderujący wraz ze mną debatę kolega doktor Bartosz Mika z Uniwersytetu Gdańskiego.

Pierwsze pytanie, pierwsza, najbardziej podstawowa sprawa, jaką jesteśmy zainteresowani, to opinia Państwa jako liderów związkowych, w jakim kierunku można, należy pójść, aby doprowadzić do rewitalizacji ruchu związkowego w Polsce, aby go wzmocnić liczebnie, czyli kwestie dotyczące tego, kto może należeć do związków, czy mogą to być też pracownicy tymczasowi, kobiety na urlopach wychowawczych, migranci czy doktoranci?

Drugie pytanie dotyczy instytucjonalno-organizacyjnych wyzwań stojących przed związkami zawodowymi, czyli tych dotyczących zmian prawnych lub organizacji dialogu społecznego. Można zapytać zatem: Jakie wyzwania instytucjonalno-organizacyjne stoją przed związkami zawodowymi, w tym te dotyczące dialogu społecznego, i na jakie dobre praktyki, osiągnięcia warto zwrócić uwagę, w tym na szczeblu województwa, branży lub regionu?

Interesująca jest też w sensie instytucjonalnym potencjalna możliwość tworzenia przy uniwersytecie lub przy kilku różnych uniwersytetach takich miejsc współpracy i doskonalenia jak Akademia Pracy, która działa przy uniwersytecie we Frankfurcie jako inicjatywa Profesora Martina Allespacha (dyrektora Europäischen Akademie der Arbeit przy Uniwersytecie Johanna Wolfganga Goethego we Frankfurcie nad Menem), a tu w Polsce tym problemem zajmowała się Agnieszka Minkiewicz z Poznania. Zastanawiamy się także na Uniwersytecie Śląskim nad inicjatywą powołania studium podyplomowego dla wspierania liderów przywództwa i rozwoju zawodowego. W każdym razie warto zastanowić się nad różnymi inicjatywami współpracy świata związkowego i świata badaczy, socjologów po to, aby promować pewien opozycyjny do liberalnego sposób myślenia, czyli takie myślenie w kategoriach społecznej gospodarki rynkowej związanej z troską o rozwiązania socjalne, oświatowe, zdrowotne służące ogółowi społeczeństwa. To wszystko mogło by też służyć kreowaniu lepszego wizerunku związków zawodowych, liderów związkowych czy ludzi o lewicowej wrażliwości w ogóle.

Rozpoczynamy zatem dyskusję od głosu Pana Jana Guza, przewodniczącego OPZZ, i liczymy na opinię w zakresie potencjalnych dróg restrukturyzacji ruchu 
związkowego w Polsce. Zdajemy sobie sprawę, że Pan Jan Guz nie jest wstanie podać tutaj wszystkich recept na rewitalizację związków zawodowych w Polsce i stworzenie rzeczywiście społecznej gospodarki rynkowej, ale mamy nadzieję na pokazanie pewnych kierunków.

\section{Jan Guz:}

Dzień dobry. Powiem ogólnie, że kto szuka „guza” w świecie stosunków pracy w Polsce, to go znajdzie. Wybrałem się zatem dziś na to spotkanie. Myślę, że będziecie więc pamiętali, kto jest z Wami. Myślę, że ruch zawodowy ma do spełnienia bardzo wiele ról, których nie sposób omówić wszystkich teraz w ciągu dziesięciu minut. Każdy jednak ze szkoły czy z domu powinien wiedzieć w Polsce, czym są związki zawodowe. Dziś jednak w szkołach trudno wiele dowiedzieć się o tym, czym są organizacje związkowe, bo głównie ta wiedza jest wykładana na lekcjach historii, bo to wtedy mówi się, że kiedyś, że w przeszłości one były i obaliły ustrój. Ostatecznie młodzi ludzie często dowiadują się w szkole tylko tyle, że kiedyś były związki zawodowe, które walczyły z pewnymi niedogodnościami systemowymi. W rzeczywistości związki zawodowe są niezbędne w zakładzie pracy też obecnie, ale powinny one być, według mnie, strefą wolności, równości, bo wzmacniają więzi społeczne. Nie jest ważny tylko komputer czy telefon komórkowy, lecz jest potrzeba, aby spotkać się, porozmawiać, pochylić się nad problemami pracowniczymi, szczególnie w dużych firmach, aby móc wesprzeć, pomóc pracownikom w załatwianiu spraw. Związki zawodowe w kraju są też podporą demokracji, bo ona by się dawno przewróciła bez nich. Piszą potem politycy, że przyjmują w Konstytucji, że związki zawodowe są ostoją demokracji, ale później z tego nic nie ma, jeśli się tego nie wdroży w życie. Jeśli napisane ustawy nie są wdrażane, nie są przekładane na język codziennego działania i funkcjonowania pracowników. W związkach zawodowych, w tych, które działają współcześnie, mamy dzisiaj duch drużyny. Przypomnę, mamy dzisiaj trzy reprezentatywne centrale związkowe zasiadające w Radzie Dialogu Społecznego, i to one przyjęły na siebie ciężar odpowiedzialności za to wszystko, co trzeba konsultować. Wielu pracowników nie zapisuje się do związków zawodowych, o tym za chwilę, ale narzekać na związki zawodowe potrafią prawie wszyscy. A to że firma, że uczelnia źle płaci... To wina czyja? Związków. A to, że są złe warunki pracy, że nie ma pokoju socjalnego... To też wina czyja? Związków, bo nie wywalczyły. Słuchajcie, ja tylko pokazuję ten obszar spraw, czyli faktycznie, jak to działanie związkowe jest ważne, bo życie składa się z tych wielu drobiazgów codziennych. Ludzie powinni więc zapisywać się do związków zawodowych.

Zobaczcie, co robi OPZZ, ja mówię o sobie, czyli od 20 lat mówiłem, że trzeba zmienić w prawie jeden drobiazg - prawo zrzeszania się w związki zawodowe. To prawo mają teraz nie tylko osoby zatrudnione, jak było jeszcze do niedawna, ale osoby pracujące, a więc pracownicy zatrudnieni na umowach śmieciowych, to też doktoranci, młodsi pracownicy naukowi, czasem starsi profesorowie. Do tych innych form umów pracowniczych teraz często się zachęca, bo mówi się

220 — „będziecie mniejszy podatek płacili”, ale pomija się wtedy to, że nie będzie 
ubezpieczeń zdrowotnych, społecznych, że nie będzie się odkładało na emeryturę. W związku z tym zaskarżyliśmy to do Trybunału Konstytucyjnego, który ciężko nad tym pracował, prosił o wyjaśnienia, prosił o komentarze. Koniec końców jednak Trybunał podjął decyzję, że nie było równości w zrzeszaniu się w związkach zawodowych, a więc, że wszyscy na tych śmieciówkach, umowach cywilnoprawnych czy zatrudnieni przez agencje pracy tymczasowej także powinni mieć prawo do zrzeszania się. Pracujący na śmieciówkach wiedzą już dzisiaj, jakie są ich interesy, i chcą się zrzeszać. To od nich słyszałem, że „gdybyśmy tu mieli związki zawodowe, to nasze miejsce pracy inaczej by funkcjonowało". No i co? Jest wyrok Trybunału Konstytucyjnego, a póki co tłoku nie ma, a według prawników oni mogą się już zrzeszać. Koledzy z „Solidarności” poszli ścieżką Międzynarodowej Organizacji Pracy, też było zaskarżenie, też uznano to prawo do zrzeszania się nie tylko osób zatrudnionych przez macierzysty zakład pracy. To, oczywiście, były emocje związane $\mathrm{z}$ tą walką o prawa pracownicze. Musi być zatem najpierw idea, potrzeba, a potem aktywność. Pamiętajmy, że związki zawodowe to są ruchy społeczne, które z potrzeb rodzą się i obumierają w zależności od potrzeb. Słyszę też często, jak pracodawcy mówią: „A u mnie nie ma związków zawodowych, bo nie ma potrzeby, co chcą pracownicy, to daję". To ja już widzę, jak im taki pracodawca daje podwyżkę wynagrodzeń, bo widzę, jak każdy boi się odezwać, żeby w ogóle się o to upomnieć. Związki zawodowe nie są więc hołubione przez kapitał, to na pewno, ale związki zawodowe przeważnie nie są też hołubione przez polityków, bo po co? Jak nie zbliżają się wybory? Związkowiec monitoruje kwestie pracowników, patrzy, krytykuje, żąda, mówi coś więcej, a to nie jest pożądane przez przedsiębiorcę $\mathrm{w}$ jego ciągłej pogoni za zyskiem. Wiem, że narzeka się na aktywność istniejących związków zawodowych, ale jeszcze raz przypomnę - pluralizm związkowy istnieje. Jeśli są środowiska, które twierdzą, że potrafią lepiej, to bardzo proszę, niech działają, to jest to minimum dziesięć osób, statut do sądu, do rejestracji i idą tłumy. Jak ktoś tak sądzi, niech próbuje. Ja to próbowałem i moi koledzy, którzy tu są na sali, czyli można. Spadek uzwiązkowienia następuje i to trzeba sobie powiedzieć. Jest w całej Europie, nie tylko w Polsce, a wynika też ze słabej aktywności społecznej. Ile osób idzie do urn wyborczych? Ile osób angażuje się w różne organizacje pozarządowe, w inicjatywy obywatelskie? Trzeba czasami mocno namawiać, motywować, żeby ta aktywność społeczna zaistniała. Związki zawodowe działają w interesie całego społeczeństwa. Krytykują nas, oczywiście, też media, wiemy dlaczego, wiemy, że czasem reprezentują konkretne interesy.

Wykorzystując różne metodologie badań statystycznych mógłbym próbować udowodnić, że do związków zawodowych należy prawie 50\% pracujących, bo jak wyłączymy umowy śmieciowe i osoby, które nie mogą się zrzeszać z różnych innych powodów, to proporcja aktywnych związkowo faktycznie rośnie. Ruch związkowy jest potrzebny, bo gdzie jest praca, kapitał, tam jest wyzysk, jak dwa plus dwa. Jak jest wyzysk i krąży pieniądz, to muszą być związki zawodowe, by upominać się o pewne ideały. Jak są związki zawodowe, to musi być dialog społeczny, musi być partner społeczny, bo jak nie będzie partnera, to nie ma z kim rozmawiać. By stać po stronie pracowników, trzeba działać, mieć organizację, 
trzeba być odważnym, zrzeszonym. Związki zawodowe to też nie jeden zakład, ale ogół. Warto tu zauważyć zmiany na globalnym rynku pracy, kwestie zmian technologicznych, zmian podejścia do wykonywania pracy, dzielenia się jej czasem. Ciągle jednak słaba jest pozycja pracownika na rynku pracy, bo pracodawcy są uzbrojeni w radców prawnych, specjalistów, profesorów, którym wtedy dobrze płacą, aby udowodnili, że związkowiec nie ma racji. Związki zawodowe osłabły także przez reformy, restrukturyzacje, zmiany struktury gospodarczej, liberalizacje gospodarki. Trzeba też powiedzieć o związkach zawodowych w kontekście nierówności partnerów społecznych, to znaczy pracodawca płaci składkę i ona jest uznawana za ciężar kosztów uzyskania przychodu, a my płacimy składkę z pieniędzy już po opodatkowaniu — z własnej kieszeni. Rząd jako partner w dialogu ma do dyspozycji wszystkie gabinety, prawników, doradców, sądy itd., a my idziemy niejako prosto z zakładu, ze sfery pracy.

Uważam, że w interesie władzy, każdej władzy — ustawodawczej, wykonawczej i sądowniczej — jest to, by istniały silne związki zawodowe, bo wtedy jest spokój społeczny. Bo symboliczne ,palenie opon” to nie tylko palenie tej opony, ale zaburzenie ogólne na rynku i zaburzenie funkcjonowania społecznego. Gdybyśmy wspólnie rozmawiali, gdyby zarówno dwustronny, jak i trójstronny dialog społeczny był silny, to pracownicy nie musieliby wychodzić protestować. Gdybyśmy teraz popatrzyli na związki zawodowe nie w perspektywie historycznej, ale w układzie teraźniejszych potrzeb, i to mimo że będzie ta postnowoczesność, komputeryzacja, cyfryzacja, to ktoś będzie musiał się ze sobą spotykać i rozmawiać. Wiem, że będą tworzyć się inne podziały na rynku pracy, że będą zmieniać się wymagania. Mimo tych zmian czy właśnie ze względu na ich powstawanie to monitorowanie rynku pracy jest bardzo ważne. Nie można też najpierw nie płacić podatków, a potem mówić, że nie ma dobrej edukacji, ochrony zdrowia, transportu publicznego, mieszkań socjalnych, że nauczycielom nie można dobrze płacić, bo wtedy faktycznie nie ma z czego płacić. Myślę, że na tym spotkaniu, w tym gronie możemy zasygnalizować wiele z tych problemów, możemy razem z Wami współpracować, po to tu dzisiaj przyszliśmy. Związki zawodowe są i mają nadzieję zyskać dzięki takim spotkaniom, dzięki współpracy ze światem akademickim. Powiem teraz ostatnie zdanie — przynajmniej w tej części — a zatem: związki zawodowe to tylko możliwość, a treścią muszą je wypełnić ci, którzy będą się w nich zrzeszać. Słowem, jak powiedziałem, jest pluralizm związkowy, który daje możliwość aktywności, działań.

\section{Slawomira Kamińska-Berezowska:}

Ten pluralizm związków zawodowych jest widoczny także teraz, dzisiaj, bo mamy tutaj w programie Pana Dominika Kolorza, przewodniczącego Zarządu Regionu Śląsko-Dąbrowskiego NSZZ „Solidarność”, czyli także najliczniejszej struktury związkowej w kraju. Pan Kolorz, jak się w ostatniej chwili okazało, w samej debacie nie jest w stanie uczestniczyć osobiście, co ze względu na nagłą niedyspozycję zdrowotną jest w pełni usprawiedliwione. Kazimierz Siciński jako

222 przewodniczący Regionalnej Sekcji Nauki NSZZ „Solidarność” go zatem zastąpi, 
a także nawiąże może do tych uwarunkowań historycznych, bo w przypadku ,Solidarności" to myślenie historyczne się jednak włącza. Mieliśmy tu do czynienia z wielką historyczną ,Solidarnością”, z potężną siłą, a dziś mamy do czynienia w XXI wieku, w 2017 roku z sytuacją zgoła odmienną, czyli trudno już o dawnej skali siły mówić. Chcemy zatem poprosić Pana Kazimierza Sicińskiego jako przedstawiciela regionalnych struktur „Solidarności” o zarysowanie problemów rewitalizacji związków zawodowych, ale ze szczególnym zwróceniem uwagi na to, co dzieje się obecnie w obszarze nauki i szkolnictwa wyższego.

\section{Kazimierz Siciński:}

Tak, przede wszystkim dziękuję za zaproszenie na dzisiejszą konferencję i za możliwości odniesienia się do różnych kwestii, też bardzo szczegółowych, dlatego że działalność związkowa jest wieloaspektowa, w tym związana z różnymi szczegółami. W naszym Regionie tak się złożyło, że mamy sekcję regionalną, która integruje wszystkie organizacje związkowe „Solidarności” w uczelniach publicznych, w instytutach badawczych i podobnych jednostkach oraz w instytutach Polskiej Akademii Nauk. Tak nie jest w innych regionach, ale u nas to działa od samego początku, to znaczy od pierwszych dni ,Solidarności” w 1980 roku, z przerwą, oczywiście, na wydarzenia okresu stanu wojennego i na delegalizację czy zatrzymanie działalności „Solidarności”. W zasadzie również w stanie wojennym, w takich trudnych okolicznościach, te nasze kontakty były pomiędzy organizacjami uczelnianymi, jednostkami badawczo-rozwojowymi czy PAN. To doprowadziło do tego, że w 1989 roku te struktury zostały odtworzone i powołane do życia już w myśl nowego statutu i nowych reguł funkcjonowania III RP. W każdym razie ten model, który jest u nas, sprawdza się, bo inaczej to dawno by się rozleciało. Te osoby, które są tutaj na konferencji z „Solidarności”, wiedzą, o co chodzi, potem to można szerzej wyjaśnić, no i w dyskusji możemy wrócić do tych szczegółów.

Organizatorzy prosili, żebym się odniósł do spraw dialogu społecznego. Odkąd pamiętam, to my ten dialog prowadzimy, staramy się go realizować w praktyce w odniesieniu do problemów, które występowały. Tych problemów była, oczywiście, cała masa. Najłatwiej je przybliżyć na przykładach z dnia dzisiejszego. Przykładowo rząd teraz w kwietniu przygotował projekt zmian o instytutach badawczych, które będą tworzyły taki Narodowy Instytut Technologiczny, w skrócie NIT. Można powiedzieć, że idea tego dużego instytutu funkcjonowała też w ,Solidarności”, ale ten model, który zaproponował rząd, był dla nas nie do przyjęcia. On zakładał na przykład pozbawienie instytutów badawczych osobowości prawnych, różnych możliwości, jakie sobie wywalczyły przez kilkadziesiąt lat, a niektóre instytucje badawcze mają blisko 100 lat historii, bo zostały powołane tuż po odzyskaniu przez Polskę niepodległości w 1918 roku, są też takie, które są korzeniami w zaborach Polski. Drugą sprawą były tu ograniczenia rozmaitych kwestii związanych z pracownikami, którzy nie byli traktowani podmiotowo, bo nagle ci pracownicy mieli być pozbawieni swoich dotychczasowych stanowisk naukowych i mieli zostać przesunięci na stanowiska wdrożeniowe. To tylko tak w skrócie, bo, oczywiście, tych problemów było znacznie więcej. My rozpoczęliśmy więc w środowisku dużą 
debatę, która zaowocowała na końcu stanowiskami Regionalnej Sekcji Nauki, Krajowej Sekcji Nauki, które były bardzo ostre, przy czym staraliśmy się tutaj też współpracować z różnymi partnerami społecznymi, zwłaszcza z Radą Główną Instytutów Badawczych. Rezultat był taki, że trochę to ostrze projektu ustawy o Narodowym Instytucie Technologicznym zostało stępione. Pewne rzeczy zostały wywalczone. Wywalczona została z powrotem samodzielność instytutów naukowo-badawczych, ale oczywiście szereg problemów pozostał. Rząd przygotował nową ustawę, ustawę o Sieci Badawczej Łukasiewicz, tak chwytliwie nazwanej „Łukasiewicz”, bo to był człowiek, który był i badaczem, i przemysłowcem, a więc potrafił kojarzyć jedno z drugim. Pod koniec jego życia okazało się też, że był to człowiek bogaty, który zarobił dzięki swoim badaniom, swoim odkryciom i wdrożeniom naukowym. Ta postać na pewno nie jest do zakwestionowania, ale sama konstrukcja tzw. Sieci Badawczej Łukasiewicz wydaje nam się w dalszym ciągu niewłaściwa. W związku z tym, co my robimy? Wykorzystujemy elementy dialogu społecznego, które są słabe w Polsce, ale są. Uruchomiliśmy w tej kwestii Wojewódzką Radę Dialogu Społecznego w Katowicach. To Dominik Kolorz, który dzisiaj, niestety, jest nieobecny, włożył sporo wysiłku, aby ten temat zafunkcjonował na Wojewódzkiej Radzie Dialogu Społecznego i efektem tego była duża dyskusja, która się odbyła w lipcu, i wystąpienie na forum rządowe ze stanowiskiem Wojewódzkiej Rady Dialogu Społecznego, czyli ciała, gdzie się podpisują nie tylko związki zawodowe, ale i strona pracodawców, i strona rządowa, dlatego że strona rządowa ma tam swoich przedstawicieli w postaci wojewody, jego zastępców, no i urzędników. Okazało się, że to stanowisko tam wypracowane było ostatecznie zbieżne ze stanowiskiem Regionalnej Sekcji Nauki NSZZ „Solidarność”. Nie będę opowiadał dalszego ciągu, bo piłka jest jeszcze ciągle w grze, bo jeszcze ta sprawa się nie zakończyła.

Analogicznie, w każdym razie, chcemy postąpić w sprawie nowej ustawy, która jest w Polsce bardzo szumnie nazywana „Konstytucją dla Nauki”, tj. tzw. Ustawa 2.0 Prawo o szkolnictwie wyższym i nauce, która zajmuje środowisko naukowe od dwu lat, można powiedzieć, odkąd mamy nowy rząd PiS, gdzie ministrem odpowiedzialnym za naukę jest Pan Jarosław Gowin. Odbyło się szereg dyskusji szczegółowych na konferencjach, które poprzedziły odbyty we wrześniu 2017 roku Narodowy Kongres Nauki. My staraliśmy się wykorzystać możliwości tego dialogu, które były na tych konferencjach. Jedna z tych konferencji była w Katowicach i dotyczyła problemów rozwoju kadry naukowej, być może też część z Państwa na tej konferencji była. Tutaj Uniwersytet Śląski okazał się doskonałym gospodarzem, aczkolwiek muszę powiedzieć, że czasami ta dyskusja szwankowała, bo mnie przykładowo udało się raz dostać głos na tej konferencji, no a na części zamykającej konferencję wiceminister, który ją prowadził, zastrzegł, że sobie nie życzy, abym zabierał głos. Tak to jest czasem z dialogiem społecznym, ale jesteśmy przyzwyczajeni do tego, że jesteśmy postponowani w niektórych kwestiach. Nie chcę tu też podnosić roli swojej osoby, ale mając możliwość zabrania głosu na Narodowym Kongresie Nauki w Krakowie powiedziałem otwarcie 224 o jednym z problemów, to był jeden z problemów szczegółowych, który jednak 
w kontekście tej Ustawy 2.0 nam się bardzo nie podoba. Mówiłem o uczelniach różnych prędkości, bo akurat ta ustawa mówi o tym, że trzeba, że tak to określę, poszerzyć stawkę, że uczelni jest za dużo. Te uczelnie były tworzone w określonych warunkach, kiedy nie było zatrudnienia, kiedy wszyscy się starali, żebyśmy mieli więcej studentów i był taki okres, że mieliśmy studentów bardzo dużo, a teraz ich liczba maleje i rezultatem jest to, że również w przyszłości zmaleje liczba uczelni. Jednocześnie wszyscy uważają, że część uczelni powinna mieć znacznie lepsze miejsce w rankingach, no ale my patrzymy na to krytycznie, bo przez to część uczelni wypadnie z obiegu. Część uczelni publicznych stanie się państwowymi szkołami zawodowymi albo uczelniami regionalnymi czy uczelniami niższych prędkości, co doprowadzi do deprecjacji szeregu ważnych środowisk regionalnych. Mam nadzieję, że Uniwersytetowi Śląskiemu uda się dostać do czołówki, bo sporo jego wydziałów zostało bardzo wysoko ocenionych podczas ostatniej kategoryzacji, ale nie ma gwarancji, że tak będzie. Ustawa zawiera też cały szereg mankamentów innego rodzaju, przykładowo ogranicza niezależność uczelni, mimo że się mówi szumnie o autonomii uczelni, to jednak ta autonomia jest ograniczana, i to w różny sposób. Nie można przecież utożsamić autonomii uczelni z poszerzeniem możliwości działania rektora, bo to nie o to chodzi, rektor i tak ma bardzo dużą władzę. Innym elementem, który powoduje ograniczenia autonomii uczelni, jest wprowadzenie Rady Uczelni, która będzie jak gdyby ciałem zewnętrznym, a na przykład jest tam taki zapis, że kandydatów na rektora będzie właśnie wyłaniała ta Rada Uczelni w większości powołana z osób spoza uczelni. Jest to więc również ograniczenie autonomii uczelni.

Inne jakieś kwestie z tym związane to ponadzakładowy układ pracy. My mówimy od wielu, wielu lat, że w szkolnictwie wyższym powinien być ponadzakładowy układ pracy, bo obserwujemy taką sytuację, że w jednym pokoju często pracują dwie osoby, a jedna zarabia 3 tysiące, a druga — być może - 30 tysięcy, oczywiście, nikt nie powie dokładnie, ile ona zarabia. Istnieje jednak taka możliwość, że osoby zatrudnione w tych samych miejscach cechuje tak wielka rozpiętość płac. Dla nas to jest niepojęte. Przykładowo w wielu miejscach jest taka tendencja, aby coś opanować za pomocą bardzo rygorystycznych algorytmów. Przykładowo dotacja budżetowa to szczegółowe algorytmy, które liczą wysokość tej dotacji dla poszczególnych uczelni $\mathrm{z}$ dużą dokładnością, a tu mamy taką sytuację, że gdzie wydaje się pieniądze na pracowników, to nie możemy doprosić się o algorytmy. Przy ocenie pracowników to wręcz niektórzy uważają, że działa tzw. punktoza, że te punkty przesłaniają wszystko inne, że liczą się przede wszystkim ludzie, którzy przynoszą punkty, bo w ślad za nimi idzie finansowanie. To nie przekłada się jednak na podobną ,punktozę”, jeżeli chodzi o wynagrodzenia, żebyśmy wiedzieli, że w tym miejscu z tymi punktami zarabia się tyle, czyli żeby wiedzieć, jaki jest model kariery, który umożliwia, że zamiast 3 tysięcy będę mógł zarobić 5-6 tysięcy czy więcej. Ten system, który teraz panuje, jest bardzo wygodny dla władzy, dla rektora, dla wszelkich służb urzędniczych, bo umożliwia wszelkiej maści manipulacje, ale nie jest dobry dla pracowników. Jest tu też masa innych mankamentów, to w dyskusji mogę te wątki rozwinąc i jestem potem do Państwa dyspozycji, bo teraz mój czas się skończył. 


\section{Sławomira Kamińska-Berezowska:}

Dziękujemy bardzo. Proponuję rzeczywiście, żebyśmy do Ustawy 2.0 jeszcze wrócili, ale może nieco później. To, oczywiście, nas też szczególnie interesuje, bo bezpośrednio dotyczy naszego środowiska. Proszę Państwa, teraz chcę zwrócić uwagę, że gdybyśmy teraz zrobili zdjęcie naszym zaproszonym prelegentom, to bardzo łatwo możemy zauważyć taką męską przewagę liczebną... Może zwłaszcza w tym kontekście warto, aby Pani Aneta Trojanowska, prezes Rady Uczelnianej Związku Nauczycielstwa Polskiego w Uniwersytecie Śląskim w Katowicach, odniosła się do obecności różnej kategorii pracowników w związkach zawodowych, w tym do obecności kobiet czy doktorantów.

\section{Aneta Trojanowska:}

Przede wszystkim bardzo dziękuję za zaproszenie na niniejszą konferencję. Dla nas, jako organizacji uczelnianej, jest ważne, by móc przedstawić opinię na temat, jak związki zawodowe powinny działać, na czym się powinny koncentrować. Proszę Państwa, moi przedmówcy przedstawili problem działalności związków zawodowych z bardziej ogólnej perspektywy, natomiast ja chcę Państwu przybliżyć, czym zajmujemy się my, jako organizacja związkowa funkcjonująca na uczelni wyższej, jakie działania podejmujemy, jakie mamy osiągnięcia, bo uczelnia wyższa jest takim zakładem pracy jak inne. Powiem to, przedstawiając działalność Związku Nauczycielstwa Polskiego w Uniwersytecie Śląskim. Uniwersytet jest naszym pracodawcą, jest bardzo dużym pracodawcą, jednym z większych w regionie, bo w tej chwili zatrudnia około 3 tysięcy 200 pracowników. Należą oni do dwóch grup, są to nauczyciele akademiccy i tzw. pracownicy niebędący nauczycielami akademickimi. Nauczycieli mamy około 1900 osób, natomiast nienauczyciele to około 1300 osób. W grupie nienauczycieli pracują osoby zatrudnione na bardzo różnych etatach i z różnymi kwalifikacjami, poczynając od robotników, kierowców, pracowników obsługi, poprzez pracowników bibliotecznych, pracowników administracyjnych, ekonomicznych, a kończąc na informatykach, pracownikach naukowo- i inżynieryjno-technicznych. Jeśli chodzi o nauczycieli akademickich, to oni też zajmują bardzo różne stanowiska, stąd bardzo duża rozpiętość ich kwalifikacji, obowiązków i zarobków. Przedstawiciele tych wszystkich grup pracowniczych należą do naszego związku, czyli Związku Nauczycielstwa Polskiego w Uniwersytecie Śląskim. Uczelniana organizacja ZNP to 626 pracowników i około 200 emerytów, jest to bardzo duża organizacja związkowa działająca w uczelni wyższej. Do niedawna byliśmy największą w Polsce uczelnianą organizacją związkową, w tej chwili o kilku członków przewyższyła nas uczelniana organizacja ZNP w Politechnice Łódzkiej. Będziemy jednak pracować nad tym, aby naszych członków przybywało, i może z powrotem to pierwsze miejsce w Polsce uzyskamy.

Parę słów o organizacji związkowej, jaką reprezentuję. Związek Nauczycielstwa Polskiego to jest jeden z najstarszych i najbardziej licznych związków zawodowych w Polsce, historia nasza liczy już 112 lat. W 1905 roku na terenach polskich, kiedy 226 tu jeszcze Polski nie było, zjednoczyli się nauczyciele, którzy pracowali w różnego 
rodzaju szkołach, i postanowili, aby nauczanie dzieci odbywało się w języku polskim. To byli ci nasi poprzednicy, w tej chwili ZNP zrzesza pracowników oświaty, którzy pracują w szkołach różnego szczebla, poczynając od przedszkoli, szkół podstawowych, średnich, kończąc na uczelniach wyższych.

Jako związek zawodowy mamy przepiękną historię. Trzeba o tym przypominać i powiedzieć chociaż kilka słów. Proszę Państwa, w czasie II wojny światowej, pojawił się na terenach Polski pewien fenomen, może o tym słyszeliście, było to tajne nauczanie, tajna organizacja Związku Nauczycielstwa Polskiego, która prowadziła nauczanie w szkołach. Wtedy nauczyciele mieli bardzo trudną sytuację, bo za coś takiego, za tajne nauczanie po polsku, groziła kara najsurowsza, czyli kara śmierci. Kilka tysięcy nauczycieli straciło wtedy za to życie. My dzisiaj, jako związkowcy, mamy łatwiej z tego względu, że nam tego typu represje nie grożą. Trzeba jednak ciągle przypominać, że nawet takimi sprawami zajmowali się kiedyś związkowcy. Myślę, że warto o tym powiedzieć, bo, tak jak wspominali już moi przedmówcy, często kreuje się w mediach negatywny obraz związkowca, a to nie jest prawda, ale celowe działanie, żeby zdeprecjonować nasze działania, żeby nam utrudnić po prostu życie.

Wracając do Związku Nauczycielstwa Polskiego w Uniwersytecie Śląskim, czyli działającego w uczelni wyższej. Związki uczelniane czy działające w placówkach badawczych są zjednoczone w podstrukturze ZNP, mianowicie w Radzie Szkolnictwa Wyższego i Nauki. W sumie Radę tworzą 72 organizacje związkowe działające w uczelniach wyższych i w placówkach naukowych, przy czym, tak jak wcześniej wspominałam, nasza organizacja jest tą jedną z najliczniej reprezentowanych. Teraz może powiem parę słów o tym, czym zajmujemy się jako związek zawodowy. Otóż, zajmujemy się bardzo różnymi problemami. Jak Pani Profesor podkreśliła, jestem kobietą, więc zajmujemy się także problemami kobiet w środowisku pracy. Proszę Państwa, kobiety na rynku pracy to prawie połowa zatrudnionych osób, szacuje się, że około $45 \%$ osób pracujących to są kobiety. Natomiast jeżeli popatrzymy na prawa kobiet, na sytuację kobiet na rynku pracy, na zarobki, na to, jak utrudnione mamy możliwości awansowania, to widzimy, jak bardzo dużo mamy tu do zrobienia jako związek zawodowy reprezentujący przede wszystkim kobiety.

W naszym związku, czyli w Związku Nauczycielstwa Polskiego, jest wyraźna przewaga kobiet, ale gdybyśmy z kolei popatrzyli na nasze władze, na naszych szefów, używając kolegialnego określenia, to tutaj mamy na górze wyraźną przewagę mężczyzn. Jest więc bardzo ważne, żebyśmy my, kobiety, na tym polu też się bardziej aktywizowały i przejmowały role liderek związkowych, bo wtedy łatwiej nam będzie zwrócić uwagę na problemy kobiet. Sprawy kobiet są ważne, ale nie jest to główny obszar naszej działalności.

Związek Nauczycielstwa Polskiego generalnie zajmuje się na naszej Uczelni tym, czym każdy związek zawodowy w każdym innym zakładzie pracy, czyli zabieganiem o wszelkiego rodzaju sprawy pracownicze, udzielaniem pomocy prawnej oraz opiniowaniem różnego rodzaju aktów prawnych. Mamy też te same kłopoty, o których już koledzy wspominali, mianowicie, że się jako organizacja 
starzejemy, że bardzo trudno nam pozyskać do związków ludzi młodych. W szkolnictwie wyższym jest to też związane ze specyfiką zatrudnienia, ponieważ ludzie młodzi, którzy robią u nas doktoraty, niekoniecznie są u nas zatrudnieni na etatach. Naprzeciwko temu wychodzi już zmieniające się prawo i pojawiła się możliwość, że doktoranci mogą należeć do związku zawodowego. Statut Związku Nauczycielstwa Polskiego został zmieniony w roku 2015 i uwzględnia taką możliwość. W tej chwili w ZNP działającym w Uniwersytecie Śląskim mamy już kilku doktorantów. Oni przecież już formalnie rzecz ujmując pracują, bo, jak Państwo pewno wiecie, mają obowiązek prowadzenia zajęć dydaktycznych. Jest to 90 godzin zajęć w semestrze, w związku z czym w zasadzie wykonują pracę zawodową.

Generalnie problem ludzi młodych w związku to jest ogromny problem, z którym się obecnie borykamy. Staramy się bardzo, aby tych młodych ludzi zachęcić i do związku przyciągnąć. W ZNP, podobnie jak w OPZZ, działają komisje młodych, w Związku Nauczycielstwa Polskiego powołano Klub Młodego Nauczyciela. Mamy też Akademię Młodego Związkowca, która została powołana w celu wspomagania umiejętności tych młodych ludzi, dla pomagania tym, którzy chcieliby przejąć role liderów. Ta akademia powstała więc dla wzmacniania ich tzw. miękkich umiejętności.

Trzeba w tym miejscu zauważyć, że często na funkcję przewodniczącego związku wybierana jest osoba, która naprawdę ma niewiele pojęcia o tym, jak się prezentować, jak występować publicznie. Nie jest prawnikiem, często nie zna obowiązujących aktów prawnych, ustaw, rozporządzeń, zwłaszcza w kontekście nieustających zmian. Powiem to na przykładzie mojej osoby, bo jestem biologiem, a ściślej genetykiem. Teraz muszę stawać przed tego typu wyzwaniami, że na przykład muszę wypowiadać się na temat różnych problemów związanych z obszarem prawa pracy i muszę posiadać znajomość odpowiednich aktów prawnych. Jest to ogromne wyzwanie. Często jest tak, że nasi liderzy związkowi takich umiejętności nie mają, stąd bardzo dobrze, że takie inicjatywy, które wspierałyby ich możliwości, się rodzą.

Kolejny obszar, gdzie my, jako związkowcy możemy wspomagać naukowców, to udział we wspólnych projektach. Podam tu przykład: w latach 2014-2016 uczestniczyliśmy jako partner społeczny razem ze Związkiem Zawodowym Górników, którego Przewodniczący Pan Potyrała jest wśród nas na sali, w realizacji międzynarodowego projektu badawczego finansowanego ze środków unijnych. Celem tego projektu było zdiagnozowanie różnicy wynagrodzenia pomiędzy kobietami a mężczyznami, którzy są zatrudnieni z tymi samymi kwalifikacjami na tych samych stanowiskach pracy. Różnicę tę określa się mianem gender pay gap - luki płacowej, jest to faktyczna różnica między wynagrodzeniami kobiet i mężczyzn. Ten projekt badawczy to była analiza bardziej pod kątem tego, skąd się ta luka bierze i co my jako związki zawodowe i jako wszyscy możemy z tym problemem zrobić, jak tę lukę zniwelować. Taka luka faktycznie istnieje. Kobiety i mężczyźni pracujący na podobnych stanowiskach nie mają równych wynagrodzeń, nie mówiąc o innych utrudnieniach, np. w awansie, gdzie mówi się o „szklanym 228 suficie” " „ „lepkiej podłodze” dla kobiet oraz o „ruchomych schodach” dla mężczyzn. 
Mogłabym dużo mówić na ten temat, bo jestem osobą bardzo zainteresowaną tą tematyką, więc dalej, w dyskusji, możemy jeszcze do tego wrócić.

W każdym razie to był właśnie taki grant, w którym było miejsce dla wypracowania wytycznych, między innymi dla parterów społecznych, które my jako związki zawodowe moglibyśmy wykorzystywać w naszej działalności. Bardzo to było dla nas owocne i ciekawe, że mogliśmy się spotkać i wspólnie pracować z naszymi koleżankami i kolegami z Wydziału Prawa naszego Uniwersytetu. Ale był to także grant międzynarodowy, w którym brali udział naukowcy i związkowcy z Wielkiej Brytanii i Włoch. Kończył się on konferencjami na bardzo wysokim szczeblu, w Komisji Europejskiej w Brukseli i w parlamencie włoskim w Rzymie. Jak wspomniałam wcześniej, nasza współpraca zaowocowała wytycznymi, które my, związkowcy, teraz możemy wcielać w życie.

Reasumując, jest to przykład takich działań, które wspomagałyby nas nawzajem - i naukowców, i związkowców. Naukowcy mają nas , pod ręką”, a my jako związkowcy możemy przedstawiać naukowcom różne nurtujące środowisko pracy problemy. Z drugiej strony, my jako związkowcy mielibyśmy wsparcie, takie bardzo solidne, ze strony naukowców, którzy mogliby podpowiadać nam pewne rozwiązania, a my stosowalibyśmy te rozwiązania w naszej praktyce związkowej.

Myślę, że na tym teraz zakończę swoją wypowiedź, ale powiem jeszcze tylko, że problemy kobiece związane ze środowiskiem pracy są mi bardzo bliskie. Niedawno, a właściwie w tym tygodniu, byłam uczestnikiem warsztatów organizowanych przez moje koleżanki ze Związku Zawodowego Górników. Warsztaty te były zatytułowane „Szare odcienie kobiecości”, a my dyskutowałyśmy o sytuacji kobiet na rynku pracy w świetle zmieniających się ostatnio aktów prawnych. Dyskusja dotyczyła wprowadzenia ustawy 500 plus, zmian w Kodeksie pracy i zmian w ustawie emerytalnej — obniżenia wieku emerytalnego. I jeszcze tylko słowo komentarza - z pierwszych badań, które były przeprowadzone teraz po obniżeniu wieku emerytalnego, okazuje się, że emerytury kobiet są dramatycznie niskie i około 80\% niższe od emerytur mężczyzn. Wynika z tego, że oprócz wcześniejszego przechodzenia na emeryturę luka płacowa w wynagrodzeniach pracowniczych, o której wspominałam wcześniej, bardzo dramatycznie przekłada się na lukę w emeryturach. O tym wszystkim my jako związkowcy musimy też pamiętać. Dziękuję bardzo.

\section{Sławomira Kamińska-Berezowska:}

Bardzo dziękuję Pani Anecie Trojanowskiej, a przy okazji chcę podkreślić, że mamy tu przykład takiej solidarności przez małe ,s” w rodzinie związkowców, czyli między Związkiem Nauczycielstwa Polskiego a Związkiem Zawodowym Górników w Polsce. Jeden związek jest zdominowany przez kobiety, drugi jest zdominowany przez mężczyzn, a mamy między nimi bardzo dobrą współpracę. Mamy też obecnego Pana Sławomira Wittkowicza, przewodniczącego Branży Oświaty i Nauki Forum Związków Zawodowych, ale także nauczyciela z wykształceniem wyższym, więc jakby mamy tu pewną kontynuację problemów oświaty i nauki. W Polsce jesteśmy też w toku procedowania zmian w ustawie o nauce i szkolnic- 
twie wyższym, a zatem warto się nad tą kwestią też nieco mocniej tutaj pochylić. Ciekawa jest też droga zawodowa Pana Sławomira Wittkowicza, też chciałam o to zapytać, o tą drogę do aktywności związkowej, bo zaczęła się ona od NSZZ „Solidarność”, a teraz reprezentuje Pan Forum Związków Zawodowych. Wszyscy, oczywiście, jesteśmy w jednej wielkiej rodzinie związkowców, to jest jedność w różnorodności. Jest to też ciekawe w kontekście wieku, mówiliśmy o wieku, a więc zwykle liderzy związkowi reprezentują wyższe kategorie wiekowe, jak to można dyplomatycznie określić. Może to jednak jest też tak, że trzeba dojrzeć do tej działalności związkowej, może trzeba zyskać pewien typ doświadczenia? Bardzo proszę, oddaję Panu głos.

\section{Sławomir Wittkowicz:}

Dobry wieczór. Z dużą przyjemnością przyjechałem do Katowic na tę konferencję. Cieszę się, że reprezentuję Dorotę Gardias — pierwszą kobietę, która stoi na czele centrali związkowej w Polsce. Nie, przepraszam, jest drugą, bo jeszcze wcześniej mieliśmy Ewę Spychalską, która przewodniczyła OPZZ, ale wśród szefów aktywnych obecnie to jedyna kobieta na tak wysokim stanowisku w polskich związkach zawodowych. Jestem, rzeczywiście, nauczycielem. Uczę historii, uczyłem w zasadzie, bo teraz jestem oddelegowany do działalności związkowej. Tak żartobliwie powiem, że jestem tutaj z jednej strony w zastępstwie Doroty Gardias, a z drugiej strony jestem zodiakalną Panną, a więc wśród obecnych prelegentów niemal jednak tę równowagę płci mamy. Dodatkowo funkcjonuję także w bardzo sfeminizowanym zawodzie nauczyciela, gdzie ponad praktycznie $80 \%$ czynnych zawodowo nauczycieli w naszym kraju to kobiety. Nie wygląda też, aby miało się to zmienić. To pewnie związane jest też z tą luką płacową, bo w którymś momencie można to tak powiązać. Działam także w Radzie Dialogu Społecznego, jestem członkiem zespołu problemowego usług publicznych, stąd problematyka szkolnictwa wyższego, jak i ochrony zdrowia i szeroko pojętej edukacji jest stale w zakresie naszych prac. Działam także w Wojewódzkiej Radzie Dialogu Społecznego, a więc mogę mówić o szansach, jak i barierach dialogu społecznego zarówno na poziomie centralnym, jak i regionalnym. Pomyślałem tak sobie, że takim pierwszym zasadniczym elementem, na który ja zawsze zwracam uwagę, to żeby być skutecznym, to przede wszystkim trzeba mieć zaufanie do partnerów po drugiej stronie i oczekiwać tego od nich. To jest, jak myślę, początek czegoś, co może przynieść jakiś efekt. Tak wynika przynajmniej z moich doświadczeń, bo dialog społeczny to ma do siebie, że on jest wpisany w konstytucję, a zatem niejako wymusza na władzy publicznej konieczność konsultowania. Premier Pawlak tak kiedyś mawiał, że tę ustawę trzeba skierować do konsultacji, bo jest tzw. przymus brukselski, a więc w związku z tym tak musimy, i musimy zapisać to i to. Tak naprawdę, bez względu na to, jakie opcje polityczne rządzą, to ten tok rozumowania pozostaje, bo chyba rzeczywiście najtrudniej zmienić mentalność rządzących, generalnie mentalność człowieka. Patrzę na to, na ten brak zaufania, jako na podstawową barierę w tym, żeby najlepiej zorganizowane grupy zawodowe, jakimi

230 dziś są bezwzględnie związki zawodowe... Tu na marginesie, chcę powiedzieć, że 
jest też sporo związków zawodowych, które funkcjonują poza naszymi trzema centralami i sobie jakoś radzą. Proszę jednak zauważyć, że z punktu widzenia władz publicznych aktywność związkowa to jest największe zagrożenie, bo zdecydowanie łatwiej zarządza się grupami, które nie są zorganizowane, są zatomizowane i stosują takie indywidualne strategie, typu, ja sobie poradzę i ten zapis mnie nie dotknie, bo jestem fantastyczny, świetny, mam masę umiejętności i jakoś osiągnę indywidualny sukces". W życiu społecznym to jednak trzeba brać pod uwagę interesy publiczne i interesy zawodowe też grup, a takie grupy zorganizowane to są właśnie związki zawodowe. Przeciętny związek zawodowy w naszym kraju ma więcej członków niż największa partia polityczna rządząca nami wszystkimi i ustalająca nam życie, bo ma prostą większość w parlamencie i jest w stanie faktycznie zadekretować wszystko, na przykład trzy środy w tygodniu. Patrzę na to z tego punktu widzenia. Wskazujemy na to jako centrala związkowa, i to bardzo różnorodna, bo w naszej konfederacji jest ponad 70 różnych organizacji, od górników począwszy, od Porozumienia Związku Zawodowego Kadra po prawie całkowicie sfeminizowany Ogólnopolski Związek Zawodowy Pielęgniarek i Położnych, bo to jest jednak potężna grupa z wielkimi problemami. Zawsze twierdziłem, że OPZZPiP to jest, chyba, najbardziej wyrolowana grupa zawodowa w naszym kraju od przełomu 1989 roku. Ponieważ funkcjonuję w sektorze publicznym i tam mam największe doświadczenia ze swojej działalności, z prowadzenia różnorodnych negocjacji w sprawach edukacyjnych czy przede wszystkim oświatowych, to wskazuję, że tak naprawdę największym problemem negocjacyjnym dla związków zawodowych w sektorze publicznym jest brak rzeczywistego partnera po drugiej stronie. Jak sobie spojrzymy na ustawę Kodeks pracy, która daje możliwość zawierania układów zbiorowych pracy, to tak naprawdę w sektorze edukacji to ona jest dostępna tylko dla nielicznej grupy pracowników niepedagogicznych, bo tutaj stroną jest wójt, burmistrz, prezydent. Natomiast już jak spojrzymy na nauczycieli, to nie ma takiej żadnej możliwości zawarcia układu zbiorowego. Słowem, 600 tysięcy ludzi w naszym kraju jest pozbawionych możliwości zawarcia czy prowadzenia rokowań zbiorowych, i to przy zapisie konstytucyjnym o dialogu społecznym, przy ratyfikowanych konwencjach Międzynarodowej Organizacji Pracy, które kładą nacisk na to, że układy zbiorowe powinny być podstawą regulacji pracowniczych, taką regulującą też prawa i obowiązki pracownicze. To się przewinęło tutaj w wypowiedzi Kazimierza Sicińskiego, który powiedział, że potrzebny jest ponadzakładowy układ pracy dla sektora nauki, ale trzeba ,tylko” zmienić zapisy prawne i tutaj jest największy problem. Chodzi o to, aby rzeczywisty właściciel, który decyduje o pieniądzach, był ustawowo umocowanym partnerem, bo wtedy jesteśmy w stanie jako związki zawodowe — bez względu na władzę, jaka by ona była - wymusić, aby usiąść do rozmów i faktycznie uporządkować sprawę w sposób korzystny dla różnego rodzaju grup, które reprezentujemy. Dokładnie to samo jest na poziomie jednostek samorządu terytorialnego, organu prowadzącego dla publicznych szkół w Polsce. Jest 600 tysięcy pracowników, a spór zbiorowy toczymy, tak jak ostatnio, z dyrektorem szkoły, na przykład o to, żeby przywrócić czy ukrócić legalne emerytury. No to konia z rzędem, żeby ten dyrektor był 
stroną do legalnie prowadzonego sporu zbiorowego. O to toczy się walka przede wszystkim, i to na różnych szczeblach, bo uderzamy zarówno do Komitetu Swobód Związkowych w Genewie przy Międzynarodowej Organizacji Pracy, ale także do różnych krajów Unii Europejskiej, dopóki Polska jest członkiem Unii Europejskiej i dopóki można wykorzystywać te elementy. Blokowanie idei zawierania układów zbiorowych w sektorze publicznym powoduje automatyczne utrudnienia w dochodzeniu swoich roszczeń, a więc praktycznie mamy ileś milionów ludzi, którzy mimo że formalnie są pracownikami i mogą się zrzeszać w związkach zawodowych, to nie mają możliwości egzekwowania swoich praw.

Tak naprawdę myślę, że jeszcze takim elementem, który wpływa na dość negatywne postrzeganie związków zawodowych w społeczeństwie, była taka wspólna polityka deprecjonowania związków zawodowych. Pamiętam, trzy lata temu byłem na takim spotkaniu z hiszpańskimi (w zasadzie z katalońskimi) związkami zawodowymi w Barcelonie i oni powiedzieli mi, że tak naprawdę, to bez względu na to, kto rządzi w Hiszpanii, to dwie rzeczy są takie wspólne, które przewijają się w dyskursie publicznym: po pierwsze słowa dotyczące urzędników publicznych jako tych, których uczciwość nie jest najmocniejszą stroną, oraz po drugie to taki stereotyp, że związki zawodowe to już w ogóle jest zło wcielone, więc że trzeba się trzymać od nich przede wszystkim z daleka. To bez względu na to, czy to rządzili socjaldemokraci hiszpańscy czy rządziły prawicowe partie. Mam takie poczucie, że w naszym kraju to też dokładnie tak samo funkcjonowało, że były tu czy są nadal negatywne stereotypy. Słowem, słyszało się, że do związków zawodowych — był taki stereotyp — kto pójdzie? Ten, kto jest słaby, kto potrzebuje jakiegoś wsparcia, pomocy, kto nie nadaje się do rzetelnej pracy, no więc szuka sobie również jakiejś tam grupy słabych i oni dadzą mu ochronę, pomoc, wsparcie i on jakoś tam przejdzie, czyli jakby to było skupisko słabeuszy. Jak dyskutujemy o Karcie Nauczyciela, to jednym z koronnych argumentów medialnych, które się przewijają, to jest, że trzeba tę kartę zmienić, bo nie można zwolnić złego nauczyciela, co jest kompletnym mitem i kompletną bzdurą. Może Karta Nauczyciela to uniemożliwiła kiedyś, gdy w 1982/83 roku miała zupełnie inne zapisy, niż ma współcześnie.

Uwzględniając współczesny punkt widzenia myślę, że to jest między innymi szansa, że jeśli jasno postawimy sobie cel, to jesteśmy w stanie zmobilizować ludzi z różnych organizacji plus osoby, które także są niezrzeszone, a to jest jakaś droga, która w dalszej perspektywie daje nam jakąś szansę. Do tego potrzebne są jednak zmiany, także w ramach nauczania zarówno w szkołach powszechnych, jak i w szkolnictwie wyższym, bo ja chciałbym, aby absolwent szkoły średniej wychodził z podstawową wiedzą o prawie pracy, o prawach i obowiązkach obywatelskich, o możliwościach działania w różnorodnych organizacjach, w tym też w związkach zawodowych. Chciałbym, aby absolwent wyższej uczelni w Polsce również wychodził z takim pakietem informacji. Nie tylko z wiedzą o przedsiębiorczości, jak on będzie jednoosobową firmą i jak będzie funkcjonował, bo wtedy nasuwa mi się przykład tego lekarza, który po 94 godzinach dyżuru w różnych systemach prawnych, bo raz był lekarzem, raz był jednoosobową firmą, a raz był jeszcze 232 kimś tam, kończy niezbyt szczęśliwie swoje życie. Myślę, że ta konferencja może 
być przesłanką do dalszych prac, do wyszukania takich elementów, które potrafią połączyć realny świat, rzeczywisty w różnych zakładach pracy: od przemysłowych, przez urzędnicze, do usługowych, ze światem nauki, bo my tego potrzebujemy jako związkowcy, ale myślę, że uczelni też potrzebny jest kontakt z rzeczywistością, z realnym światem. Dziękuję.

\section{Sławomira Kamińska-Berezowska:}

Jesteśmy wdzięczni za wszystkie Państwa wystąpienia i myślę, że teraz w toku dyskusji możemy się zastanowić, jakie instytucjonalne połączenia możemy tworzyć, co możemy zrobić, aby stworzyć lepszy zakres komunikacji między światem ruchu związkowego a środowiskami akademików i socjologów. Pomysłów jest wiele, w tym ten dotyczący stworzenia analogicznej jak w Niemczech Akademii Pracy. Problemem jest też, czy przykładowo takie nasze spotkanie potraktujemy jako jednorazowe, czy też wypracujemy pewne formy kontynuacji tego typu spotkań, chociażby przy okazji konferencji z cyklu „Społeczne granice pracy”. Otwieram zatem dyskusję.

\section{Jan Guz:}

Dyskusje o związkach zawodowych nigdy się nie kończą, bo dyskusje o związkach zawodowych to dyskusje o życiu ekonomicznym, o życiu codziennym ludzi, o demokracji, których związki zawodowe są podstawą. To jest dyskusja o prawach pracowniczych, o tym, jak się lepiej organizować, gdzie, kiedy i w jakich przypadkach można uzyskać pomoc. W związku z tym w tej chwili powinniśmy wziąć pod uwagę też ramy czasowe przy dyskusji i przy pytaniach, komentarzach z sali.

\section{Barbara Surdykowska:}

Bardzo wiele wątków się, oczywiście, pojawiło, ale wydaje mi się, że takim naprawdę kluczowym wątkiem jest pytanie o to, jak postrzegamy rolę związków zawodowych z perspektywy mikro i makro, np. jak postrzegamy rolę zbiorowych układów pracy z punktu widzenia makroekonomicznego. Biorąc pod uwagę dynamikę wzrostu płac nie wymyślono niczego innego, żadnej innej metody, która przekłada się na popyt wewnętrzny, na pewną stabilność makroekonomiczną, jak osiągnięcie tego za pomocą właśnie negocjacji zbiorowych. Nie chcę przedłużać, ale obawiam się, że my zawsze przy okazji różnego rodzaju spotkań w tym momencie kończymy, np. mówimy — potrzebujemy układu zbiorowego pracy, a zapominamy o tym, że to wysokie pokrycie pracowników układami zbiorowymi, z czym mamy do czynienia w niektórych państwach Europy Zachodniej, starej Unii, wynika z określonej publicznej polityki państw, z określonych decyzji, które przekładają się później na rozwiązania legislacyjne, takie jak generalizacja układu zbiorowego. To nigdzie nie jest tak, że samą siłą związków zawodowych i organizacji pracodawców udaje się uzyskać właśnie takie bardzo wysokie pokrycie pracowników układami zbiorowymi, które ma określone konsekwencje makroekonomiczne. Teraz nawet jeżeli to założymy, to dopiero wtedy rodzi się największe pytanie czy najtrudniejsza kwestia. To właśnie jest pytanie dla ekonomistów, socjologów, to właśnie jest 
płaszczyzna tej nieistniejącej współpracy: świat nauki — świat ruchu związkowego. Dobrze, że pewne rozwiązania powstawały w latach 50., 60. XX wieku, kiedy pewne relacje między pracą a kapitałem wyglądały zupełnie inaczej. Jakie narzędzia powinny być użyte teraz, kiedy nie doczekaliśmy się żadnej struktury stosunków przemysłowych, która powstała po roku 1989, która byłaby stabilna i zapewniałaby równowagę między pracą a kapitałem? Często mówi się tak — „to zastosujmy pewne narzędzia, które się sprawdziły tam, w Europie Zachodniej”, ale one się sprawdziły tam np. kilkanaście, kilkadziesiąt lat temu i widać, że obecnie, czyli szczególnie w okresie pokryzysowym ze względu na wszelkie zalecenia Komisji Europejskiej - już nie chcę tu tego wszystkiego rozwijać — narzędzia te nawet w Europie Zachodniej zaczynają się wykruszać. Były pewne mechanizmy, które sprawdzały się, ale dalej nie są już adekwatne. To są te olbrzymie, w moim odczuciu, pytania, dotyczące tego, jak osiągnąć tą właśnie równowagę pracakapitał, ale mechanizmami, które byłyby adekwatne do obecnej, zglobalizowanej gospodarki, do działania korporacji międzynarodowych, których rola jest w Polsce obecnie znacznie większa.

Brakuje mi w tych debatach takiego kreatywnego myślenia, bo odwołania do pewnych mechanizmów, które już gdzieś, kiedyś się sprawdziły, niekoniecznie oznaczają, że one sprawdzą się teraz tutaj w zupełnie innej sytuacji społecznej i ekonomicznej.

\section{Julia Kubisa:}

Przede wszystkim chciałam podziękować za zorganizowanie tej debaty, która jest bardzo ważna dla naszego środowiska socjologów, socjolożek pracy. Tej wymiany myśli między środowiskiem związkowym i akademickim dotyczy moje pytanie do Państwa, po pierwsze: Gdzie widzicie sojuszników i z kim chcielibyście współpracować i uzyskiwać wsparcie i inspiracje, z którymi grupami badaczy, z którymi organizacjami, czyli gdzie widzicie te potencjalne sojusze?

Drugie pytanie: Jakie są Wasze oczekiwania, tak mówiąc szeroko, wobec środowiska naukowego? W jaki sposób wyobrażacie sobie naszą współpracę i jaką dozę naszego krytycyzmu jesteście w stanie przyjąć? Dziękuję bardzo.

\section{Agnieszka Mińkowska:}

Jesteśmy tutaj na sali w towarzystwie osób „przekonanych”, w większości przypadków osobiście zaangażowanych $\mathrm{w}$ ruch związkowy. Mam jednak wrażenie, że współczesna działalność związkowa nie jest „nośnym” tematem w Polsce, nawet poznawczo dla środowisk akademickich, także z zakresu nauk społecznych. O procencie przynależności do związków zawodowych i stereotypizacji postaci „Związkowca” w Polsce nie wspominając. W kontraście, jak się okazuje, do krajów tzw. starej Unii Europejskiej, gdzie nie tylko wskaźniki ekonomiczne od lat są dużo lepsze, ale także ruch związkowy wydaje się w miarę opierać globalizacji, a właśnie warunki pracy i płacy stanowią nadal nieosiągalne marzenie dla wielu Polaków, którzy zdecydowali się nie emigrować i „pchać ten

234 wózek" tu, na miejscu, w kraju. 
Przyczyn takiego stanu zapewne jest wiele. Jednym z tropów może być, moim zdaniem, systemowy brak obecności w Polsce zagadnień związanych z prawem do partycypacji pracowniczej i ogólnie brak zainteresowania mechanizmami demokracji partycypacyjnej oraz znaczenia, jakie ma ona dla społeczeństwa — jego kondycji, dobrostanu, a w tym przypadku — także warunków pracy obywateli kraju o takim modelu ustrojowym.

W Polsce nie można uzyskać na przykład stopnia chociażby licencjata z zakresu relacji przemysłowych (industrial relations). A jest to kierunek czy może bardziej: interdyscyplinarna specjalizacja, obecna w systemie kształcenia akademickiego starej Unii Europejskiej już od lat 60. XX wieku. Specjalizacja przyporządkowana zależnie od tradycji i profilu danej uczelni do wydziałów nauk ekonomicznych, społecznych bądź politologicznych. Tak czy inaczej — jest i daje konkretne, może niszowe, ale kompetencje, a tak „skonfigurowani” absolwenci „wsiąkają” od lat w zachodni rynek pracy, zasilając między innymi szeregi urzędników, dyplomatów, menagerów, a nawet prawników i nikt się temu specjalnie nie dziwi... Nawet w kontekście teoretycznie mainstreamowego neoliberalizmu. Przypadek niebytu „relacji przemysłowych" w dyskursie polskim przypomina nieco bardziej może „sexy” historię polskich zmagań z zagadnieniem gender. Pojęcie wywołujące wciąż w naszym kraju liczne emocje, niekiedy irracjonalne nagonki, w czasie gdy na tzw. Zachodzie terminologia związana z tym kierunkiem (jednym $\mathrm{z}$ wielu w tym obszarze poznawczym) ma od dziesięcioleci usystematyzowaną pozycję i jest stałym punktem w kształceniu na przykład antropologów kultury, psychologów społecznych czy socjologów i nie wywołuje specjalnych emocji, tym bardziej na forum politycznym. Analizując ten przypadek, podobnie jak ogólny brak rozpoznania, ale też prawdopodobnie potrzeby zainteresowania się zagadnieniami relacji przemysłowych w Polsce, można odnieść wrażenie, że otwarcie nauk społecznych może więc jeszcze nie nastąpiło. Brak dostrzegania znaczenia kształcenia w kierunku rozwijania kompetencji partycypacyjnych obywateli na różnych poziomach (począwszy od wspierania przez związki zawodowe, państwowe instytucje kontrolne oraz środowiska uniwersyteckie samorządów szkolnych — jak to ma miejsce przykładowo w Szwecji) w kraju teoretycznie starającym się o utrzymanie statusu demokracji partycypacyjnej - zastanawia.

Mamy tu więc na chwilę obecną taki neoliberalizm strukturalny, nie tylko w obszarze gospodarki krajowej, ale także w systemie nauczania, szczególnie w zakresie ekonomii. Brakuje nam interdyscyplinarnych platform, stworzonych pod kątem kształcenia w kierunku social justice (sprawiedliwości społecznej), kolejnego terminu nieobecnego w curriculum akademickim w Polsce. Brakuje edukacji skalibrowanej bardziej na człowieka, antropologicznie. Mam wrażenie, że po wejściu do Unii całe kierunki studiów w Polsce zostały przeformułowane pod kątem stricte biznesowym. Nie nastąpił rozwój stosowanych nauk społecznych i ekonomicznych osadzonych bardziej w kontekście socjalnym, profilowanych też „pod” sprawiedliwość społeczną. Systemowo to nadal bardzo kuleje, a efekty takiego obrotu spraw obserwować można na wielu płaszczyznach. Za najbardziej niepokojący uważam ogólny, systematyczny spadek partycypacji społecznej — 
obywatelskiej. Narzędzia demokracji nie są do końca przez nasze społeczeństwo wykorzystywane. Widać to chyba najbardziej wyraźnie na poziomie partycypacji w wyborach, zwłaszcza samorządowych. Podobnie nie najlepiej wygląda zaangażowanie się obywateli w procedury konsultacji społecznych, zarówno na poziomie osiedla/gminy, jak i w przypadku konsultacji w sprawie projektów legislacyjnych. Przypadki akcyjnych reakcji tak zwanego społeczeństwa wobec konkretnych zdarzeń niestety nie świadczą o systemowym zaangażowaniu się oraz pracy obywateli nad skutecznością narzędzi współdecydowania. Zaangażowanie w ruch pracowniczy, czytaj: związki zawodowe, jest w Polsce postrzegane mówiąc najogólniej - bardzo retro.

Jako dygresja - mnie samej zajęło trochę czasu dokonanie swoistego coming outu, aby móc otwarcie i bez stresu przyznawać się do przynależności związkowej. Także na poziomie czysto towarzyskim, mimo że obracam się w środowisku wydawałoby się bardzo „postmodernistycznym”, jednak pewien problem z percepcją aktywności związkowej nawet wśród polskiej „alternatywy” występuje. Można przywyknąć, ale...

W kontekście reformy polskiego szkolnictwa, w której proponuje się między innymi ograniczanie autonomii uniwersytetów i „zdjęcie” działalności naukowej z niektórych instytucji szkolnictwa wyższego na rzecz kształcenia stricte pod wytyczne i wyniki finansowe placówki, może doprowadzić do dodatkowego osłabienia zainteresowania tematami niekomercyjnymi i niszowymi. A do takich niestety zalicza się w Polsce problematyka partycypacji obywatelskiej, pracowniczej czy sprawiedliwości społecznej. Wydaje mi się, że społeczna odpowiedzialność nauki jest równie istotna, jeśli nie istotniejsza od społecznej odpowiedzialności biznesu...

\section{Adam Mrozowicki:}

Ja bym aż tak surowo nie oceniał środowiska naukowego, jeśli chodzi o zainteresowania sprawami związkowymi, bo wydaje mi się, że istnieje dość duże doświadczenie pracy z konkretnymi komisjami zakładowymi, że występujemy jako eksperci analiz opinii pracowników etc. Jest raczej problem, jak to Julia mówiła, tych oczekiwań, czyli jak mamy mówić, żeby się słyszeć wzajemnie. To jest problem. To jest taka praca u podstaw, organiczna, która gdzieś tam się odbywa. Te próby wspólnego budowania mostów, one wymagają wypracowania jakiegoś wspólnego języka, gdzie nie instrumentalizujemy się nawzajem. To też jest bardzo ważna sprawa dla obu stron. To jest pytanie, kiedy jest potrzebna Akademia Związków Zawodowych, kiedy środowisko akademickie jest w stanie z tego korzystać, że ma współpracę ze związkami zawodowymi, a kiedy to działa w drugą stronę? To są pytania, których my sobie nie zadajemy często.

Mam wrażenie, że większość moich socjologicznych znajomych działa w związkach zawodowych, na przykład zasila takie organizacje, jak Inicjatywa Pracownicza. Zasięg tego typu organizacji w środowisku akademickim jest dosyć duży, podobnie jak prób wejścia czy zorganizowania takich środowisk, które zostały

236 opuszczone przez związki zawodowe, jest dosyć znaczny. Mówię o środowiskach 
NGO-sów, o środowiskach artystycznych. To takie rzeczy się dzieją i to jest pytanie, w którym miejscu w tym naszym dialogu jest pomysł na to, by wchodzić tam, gdzie związków jeszcze nie ma. Duże zakłady pracy, jak Pan Przewodniczący Jan Guz to określił na samym początku, to w nich są zorganizowane związki, a jeżeli nie są zorganizowane, to dlatego, że ,zniknęły” po prywatyzacji, to zresztą związki zawodowe pewnie są same w stanie najlepiej ocenić te powody, dla których brakuje organizacji związkowych w niektórych takich zakładach, na przykład w handlu. Problemem jest to, że u nas większość pracowników pracuje w mikroprzedsiębiorstwach, że młodzi ludzie pracują na umowach cywilnoprawnych i nie wstępują do organizacji związkowych nie dlatego, że nie mogą, ale dlatego, że nie widzą w związkach zawodowych sposobu rozwiązania swoich problemów. To jest jakby kolejny problem i wyzwanie do rozwiązania.

\section{Agnieszka Mińkowska:}

Mam dużo tego typu dylematów jako pracownik związku zawodowego. Analizując sukcesy organizacji związkowych w krajach tak zwanej starej Unii i tropiąc przy okazji ,,patenty” na rozwój społeczeństwa obywatelskiego, widzę, jak bardzo istotne jest rozwijanie współpracy związkowej z różnego typu instytucjami i organizacjami pozarządowymi, aby tworzyć solidne zaplecze, gromadzić tak zwany kapitał społeczny. Wsparcie i kompetencje świata akademickiego są tu, myślę, kluczowe. Dzięki synergii można na przykład „wypracować” kompetentną kadrę związkową, podnosić kompetencje liderów, także w oparciu o współpracę z NGO-sami. Może to także zapobiegać ewentualnej radykalizacji związków zawodowych, a szerzej też rozwojowi postaw nacjonalistycznych, ksenofobicznych w środowiskach pracowniczych (a więc wśród obywateli), a takie zagrożenia, jak wiemy, realnie istnieją. Na przykład model niemiecki związków zawodowych zakłada strategiczne planowanie rozwoju, z uwzględnieniem „kształcenia ustawicznego” środowisk związkowych, z naciskiem na kluczowych liderów. Dzięki wypracowanej współpracy „międzyinstytucjonalnej” DGB centrala federacji związków zawodowych w Niemczech stara się świadomie i systemowo kształtować kompetencje liderów i zapewnić im wsparcie merytoryczne ekspertów, wywodzących się właśnie często z czynnego świata akademickiego. Przykładowo Uniwersytet we Frankfurcie nad Menem posiada przy wydziale nauk społecznych i ekonomicznych odrębną jednostkę kształcącą, dedykowaną właśnie związkowcom: Akademie der Arbeit, gdzie związki zawodowe, ale też niekiedy organizacje pozarządowe mogą oddelegowywać osoby, z którymi wiążą swoje nadzieje. Akademia funkcjonuje między innymi dzięki możliwości korzystania z infrastruktury uczelni. Program studia zawiera bloki tematyczne z zakresu nauk ekonomicznych, prawnych i społecznych. Tego typu akademii jest w Niemczech więcej. Innym przykładem może być Szwecja, kraj o najwyższym na świecie uzwiązkowieniu, gdzie $70 \%$ osób pracujących to związkowcy, a $88 \%$ pracujących objętych jest porozumieniami co do warunków pracy i płacy wynegocjowanymi przez związki zawodowe. W Szwecji istnieje cały system instytucji, niekiedy wręcz budżetowanych trójstronnie, wspierających model partycypacji obywatelskiej, w tym związki zawodowe jako 
przedstawiciela pracowników, a więc „,produktywnej części” społeczeństwa. Cała Skandynawia to generalnie zbiór ciekawych tak zwanych dobrych praktyk w tym zakresie. Włosi i Brytyjczycy może wypadają przy Skandynawii skromniej, ale też mają się czym pochwalić, podobnie jak Benelux, Hiszpania. Przykładów jest więcej. Nie jest to na pewno mainstream, ale jest co analizować.

Tego typu systemowe rozwiązania z pewnością wpływają na jakość dialogu społecznego i pomagają unikać radykalizacji, nie tylko w szeregach tak zwanych partnerów społecznych, ale także po stronie pracodawców i grupy rządzącej. Zaplecze akademickie wydaje się odgrywać w tych przypadkach bardzo dużą rolę zarówno bezpośrednio - wspierając merytorycznie działaczy, ale też w szerszym znaczeniu, poprzez kształcenie - wpływając na postawy i „kondycję mentalną" społeczeństwa, w tym grupy urzędniczej i kadr pracodawców.

\section{Krzysztof Jasiecki:}

Dostałem informację od organizatorów, że ze względu na ograniczenia czasowe mój głos jako przedstawiciela środowiska akademickiego uczestniczącego w tym panelu ma być tym ostatnim, bo wskazane jest przestrzeganie rygorów czasowych. Postaram się zatem mówić zwięźle. Jako profesor socjologii poczułem się wezwany do głosu i mogę powiedzieć tylko tyle, że tak się złożyło, że polska transformacja nałożyła się na zmiany w systemach edukacyjnych wprowadzanych w Europie Wschodniej, które polegały na tym, że ruchy pracownicze z punktu widzenia elit tworzących nowy system nie były funkcjonalne wobec kierunku przemian ustrojowych. W związku z tym z programów akademickich wiele tych kwestii wypadło, ucierpiała zatem socjologia pracy i socjologia stosunków przemysłowych. Mamy jednak obecnie kryzys neoliberalizmu i może czas zacząć dyskutować o tym, że skoro chcemy przebudowywać system społeczny, chcemy zmieniać model kapitalizmu w Polsce, to jakie jest miejsce związkowców, jakie jest miejsce środowisk akademickich, jakie jest miejsce współpracy tych dwóch środowisk? Tak się kiedyś składało, że bliska współpraca związkowców i środowisk akademickich leżała u podstawy sukcesu „Solidarności”, bo przekładała się ona na inną siłę wpływu ruchu pracowniczego. Teraz pytanie: Skoro mamy taką sytuację, to co możemy zrobić? Koledzy i koleżanki wyszczególnili katalog problemów, które powinny być przedmiotem dyskusji. Czy to nie jest moment na bliższą współpracę, na sformułowanie oczekiwań i wzajemne rozmowy? Tak się składa, że w odróżnieniu od Państwa nie jestem związany instytucjonalnie ze związkami zawodowymi, tylko z organizacjami pracodawców, typu Krajowa Izba Gospodarcza czy Związek Banków Polskich. Chcę jednak powiedzieć, że sytuacja, jaka się pojawiła na rynku pracy — deficyt pracowników, świadomość, że za chwilę to uderzy w konkurencyjność polskiej gospodarki, problemy z innowacyjnością czy z kapitałem społecznym - powoduje, że biznes też zaczyna zmieniać nastawienie do tych zagadnien. Widzę tu pewną szansę, aby spróbować zmotywować partnerów społecznych, a związki zawodowe z natury rzeczy mogą to inicjować i rozmawiać w kategoriach łączenia tych potencjałów, na przykład 238 w Krajowej Izbie Gospodarczej uczestniczyłem w dyskusji na temat partycypacji 
pracowniczej w wymiarze własnościowym, co można uważać za punkt wyjścia do dyskusji o innych wymiarach partycypacji pracowników. Przykład: Europejski Indeks Partycypacji pokazuje, jak niskie jest miejsce Polski w tym zakresie. To wymowny paradoks. Nasz kraj, który miał silne struktury związkowe (i to był nasz benchmark pokazywany w świecie), obecnie w zakresie partycypacji pracowniczej znajduje się na końcu statystyk europejskich. Można postawić pytanie, a co się zmieniło pod tym względem w okresie „dobrej zmiany”? Mam wrażenie, że oficjalnie się robi coś dla podniesienia podmiotowości świata pracy, na przykład podnosi płacę minimalną wyżej, niż chcą związki zawodowe, ale dzieje się to przede wszystkim w konwencji klientelizmu, nie partycypują w tym istotnie związkowcy, nie partycypują też inne organizacje społeczne. Mamy raczej do czynienia ze wzmocnieniem paternalizmu i etatyzmu, który związki ogranicza do roli bazy poparcia (kolejnej wersji ,pasa transmisyjnego” woli partii przekazywanej pracownikom).

Jeśli Państwo mówiliście tutaj, na przykład Pan Kazimierz Siciński, jaki jest problem w przekonaniu rządu, że propozycje zmian powinny uwzględniać stanowiska „Solidarności”, to patrząc z zewnątrz, mamy do czynienia z paradoksem, bo „Solidarność” jest silnym komponentem rządzącego bloku władzy. Dla mnie jako badacza dialogu społecznego rodzi się ciekawe pytanie, co się dzieje na przykład w reformie edukacji, żeby o podmiotowości związkowej, o której Państwo mówiliście, coś z treści tych programów nauczania się dowiedzieć, bo raczej moi koledzy mówią, że usuwa się elementy podmiotowości społecznej z programów nauczania, nie tylko związkowe, ale związkowe również i nie chodzi mi o związki zawodowe tylko, bo w szerszej perspektywie związki zawodowe są jednym z elementów społeczeństwa obywatelskiego. Destrukcja związków zawodowych w latach 90. spowodowała również, że mamy bardzo słabą demokrację w sensie partycypacji, bo w ich miejsce nie weszły żadne inne masowe struktury. To jednak było robione systemowo i ci, którzy wprowadzali te reformy, o tym mówili, że ruch związkowy był dysfunkcjonalny wobec transformacji. Podobno mamy zmienić ten model. Ale... istnieje Rada Dialogu Społecznego, konflikt w służbie zdrowia, który rozwiązuje się poza Radą (podobnie jak ustawa ograniczająca handel w niedziele), są sygnałami, że jest to instytucja w znacznej mierze fikcyjna. Jeśli chcemy rzeczywiście zmienić nasz ustrój instytucjonalnie w sposób trwały, to gdzie jest w nim miejsce związków zawodowych, gdzie jest miejsce partycypacji obywatelskiej, gdzie jest miejsce kadry profesorskiej? Przykładowo, gdy uruchomię telewizor i słyszę, że nowa konstytucja będzie pisana bez elit, to jest pytanie przez kogo, jak i dla kogo będzie pisana...

Tytuł profesora zwyczajnego nadał mi Prezydent RP w związku z tym w sensie zawodowym mogę powiedzieć, że należę do elit i zadaję pytanie: dlaczego mam być wyłączony z kształtowania konstytucji, z dyskusji nad nowym ustrojem? Jako socjolog zauważam sprzeczny ze standardami demokracji sposób traktowania obywateli w debacie o nowym ustroju, która ma zostać przekształcona w referendum, ale nikt jeszcze nie sformułował jakichkolwiek zagadnień i nie wyraża w sposób jasny i zrozumiały, jakie ma być w nim miejsce organizacji społecznych, 
związków zawodowych czy innych organizacji obywatelskich. Myślę, że jest to nasz wspólny interes, by tego typu problemy akcentować i organizować formy współpracy związkowców i świata akademickiego.

W odróżnieniu od początku lat 90., kiedy znaczna część inteligencji przechodziła do prywatnego biznesu, robiła kariery w obsłudze nowo tworzących się instytucji, dzisiaj widzimy, że ten model się wyczerpał i środowiska akademickie też odczuwają pauperyzację i odczuwają obniżenie swojego statusu. Mówiliście Państwo o umowach śmieciowych, o nowych typach karier na uczelni, które rozpoczyna się w żenująco niekorzystnych warunkach startu zawodowego i społecznego. Czego można oczekiwać od ludzi, którzy są zatrudnieni na uczelniach pod warunkiem, że przyniosą grant, który wygrali. Będą zatrudnieni na dwa lata albo na trzy. Nie ma sensu inwestować w siebie, po to, żeby po dwóch latach ktoś powiedział — „No nie ma Pan grantu, to do widzenia i rób sobie coś innego". Nasza dzisiejsza dyskusja pokazuje, ile jest takich pól aktywności i o czym powinniśmy rozmawiać. Jak to zrobić, jak to zorganizować, to może w następnej części porozmawiamy. W każdym razie sygnalizuję, że to jest jeden ze strategicznych problemów i on się nie ogranicza do kwestii płacowych, ale to jest problem systemowy — czy mamy być podmiotami współpracującymi ze sobą i wpływającymi na ustawy, czy mamy się dowiadywać, że ktoś w trybie nocnym przyjął ustawę, która nas uszczęśliwi, bez pytania nas o opinię, zdanie jako ekspertów, działaczy społecznych, związkowców itd.

\section{Sławomira Kamińska-Berezowska:}

Zwieńczeniem tego spotkania, jak się umówiliśmy, mają być teraz głosy i komentarze zaproszonych prelegentów reprezentujących stronę społeczną. Bardzo prosimy.

\section{Jan Guz:}

Szanowni Państwo, wiem, że nie uda się tutaj odpowiedzieć na wszystkie pytania, choć są bardzo przekrojowe i istotne. Od końca zaczynać może łatwiej, a zatem Pan Profesor Jasiecki pyta „Jak to zrobić?” Odpowiadam: „Najłatwiej byłoby wygrać wybory i wprowadzić pewne nowe działania w życie”, chociaż, jak obserwuję chociażby samorząd, to potem okazuje się, że osoby o wykształceniu pedagogicznym, które później działają w samorząazie, nie zawsze traktują jako priorytet problemy edukacji, ale tu może odchodzę o tematu. Szanowni Państwo, konsumpcyjny model życia, który w ostatnich latach został nam zaszczepiony, powoduje, że przychodzimy do związków zawodowych jak do sklepu, mam problem, nie wiem, jak to rozwiązać, potrzebuję pomocy, to idę do związków zawodowych, a to organizacje związkowe powinny tworzyć osoby aktywne, które mogą pomóc i dać z siebie coś innym.

W związku z tym dzisiaj jest oczekiwanie od organizacji związkowych, ja bym powiedział, aktywności, zorganizowania się, bo, słuchajcie, te organizacje będą nam wszystkim potrzebne, może nie dziś, może nie jutro, ale za tydzień za dwa.

Nie chcę być, szczególnie na tym spotkaniu, krytykiem tego rządu czy 240 poprzedniego rządu, bo nie rzecz chyba w tym, ale związki zawodowe osłabły 
w procesie transformacji. Kiedy mówimy o tym, że kiedyś Polska była tym dobrym przykładem uzwiązkowienia, walki związkowej, oczywiście, niejednokrotnie, jakbym do historii sięgnął, ale zobaczcie, co się stało. Ci, którzy byli wówczas związkowcami czy dziś odwołują się do tego, bo zobaczcie, ilu ludzi dzisiaj pisze w swoich życiorysach „działacz związkowy”, nie będę wymieniał tego czy innego związku. Z drugiej strony mówią, że u związkowca, który został pracodawcą, być pracownikiem to jest ciężki chleb, czyli to tak jakby ci związkowcy odbili się od bazy, odeszli od tego, co robili, i zapomnieli czy zgubili ideały. Przecież pierwsze rządy po zmianach w 1989, po reformach tworzyli było nie było doradcy związkowi, związkowcy. Dzisiaj piszą po nocach ustawy, oczywiście, najbardziej mnie boli ta z 16 grudnia, tak zwana kolumnowa, wyłączająca związki zawodowe z partycypacji pracowniczej, ale chociażby też te, które w ostatnich dniach powstają, na przykład o deputacie węglowym, gdzie pisze „uprawnieni”, przecież jakby to było skonsultowane, to byśmy zwrócili uwagę, że to nie jest taka prosta interpretacja słowna, że może rodzić i będzie to rodziło wiele konfliktów. Ustawa kolumnowa, która też w nocy została przyjęta i później trzeba było szybko robić poprawki. Nie ma, oczywiście, dialogu, jest raczej taki „parasol” ochronny, że niby my coś konsultujemy. Jak władza jest silna, to wcale nie chce rozmawiać, jak będzie słaba, to może coś, ale też nie będzie podatna za bardzo, a mówię to jako praktyk w Radzie Dialogu Społecznego, trójstronnego organu. W związku z tym stawiacie pytanie, jakie narzędzia powinny być użyte w działaniu związkowym. Nie ma gotowej recepty, bo to zależy od zakładu i konkretnych sytuacyjnych uwarunkowań, od stopnia zorganizowania, od partnera społecznego w postaci pracodawcy. Natomiast świat nauki jest nam niezbędny, oczywiście, bo nawet jak Szanowni Państwo opracujecie prognozy czy zasady działania bardzo takie użyteczne, to gdzie to sprawdzicie? Każdą maszynę trzeba sprawdzić w praktyce. W związku z tym trzeba teorii i trzeba sprawdzenia jej, nie tylko przez sondaże, ale poprzez praktyczne oceny, jak to funkcjonuje. Zaplecze naukowe, oczywiście, jest potrzebne do tego, żeby radzić, proponować, poszukiwać dobrych rozwiązań. Związkowcy, w tym wielu moich kolegów i koleżanek, mówią — „no ja wiem, jak jest w zakładzie, jak jest w kopalni, ja wiem, że to jest źle, ja to czuję, tylko trzeba to naprawić". Na przykład teraz, te wszystkie ustawy, jakie powstały w wyniku działania rządu, sejmu, trzeba umieć zinterpretować i wykorzystać do naprawy. Nie można też wyjąć jednej cegiełki, dwu cegiełek, bo się może wszystko poprzewracać, tylko trzeba to właściwie budować. Z Panem Profesorem Jasieckim to czasem rozmawiamy i też zadałbym pytanie: „Panie Profesorze, a co na to dialektyka?” Można budować teorie, ale one powinny być sprawdzalne i my staramy się to w związkach zawodowych robić.

Trzeba też poszukiwać sojuszników, bo sami zginiemy przy pierwszej wojnie. Jest to też zadanie dla związkowców, aby współpracować ze sobą, bo ani samo OPZZ ze swoimi 80 organizacjami branżowymi, w tym ZNP — największą organizacją związkową, górnicy — ZZG... Właśnie tu podkreślę, że ZZG w Polsce wie, jak ważne są sojusze, że bez innych związków zawodowych tej branży trudno będzie przeprowadzić pewne działania. Rządzący za to bardzo sprytnie czasem 
działają i wyjmują jedną, dwie organizacje i próbują przekonać, przekupić w jakiś sposób do swoich racji. W związku z tym musimy działać wspólnie, jako centrale związkowe, jako organizacje związkowe. Nieraz już też udowodniliśmy, że jak działamy wspólnie, mamy lepsze rezultaty. Sam też zawsze w swoim działaniu staram się, na tyle, na ile mogę, być otwarty wobec świata. Robimy wiele spotkań, jak też uczestniczymy w wielu debatach, jak ta dzisiejsza, którą — mam nadzieję — będziemy kontynuować.

\section{Kazimierz Siciński:}

Jeżeli można, to krótko, choć trudno mówić krótko o takich złożonych problemach. Po pierwsze, wywołałem tu problem układu zbiorowego pracy na uczelni publicznej i o tym chciałem za chwilę jeszcze parę słów powiedzieć w dalszym ciągu. Padła tu też kwestia współpracy międzyzwiązkowej. Ja myślę, że akurat w naszym środowisku to tej współpracy międzyzwiązkowej jest bardzo dużo i jest bardzo dużo takich przykładów, bo to jest i na tym forum regionalnym, to my z ZNP mamy dużo wspólnych tematów i dużo kwestii, które rozwiązujemy. $\mathrm{Z}$ naszego środowiska wywodził się jeden z kolegów, który potem działał i chyba w dalszym ciągu działa na forum ogólnopolskim i często go spotykałem w sejmie przy dyskusjach budżetowych czy innych kwestiach związanych z nauką i szkolnictwem wyższym. Z Forum Związków Zawodowych to my mamy też wieloletnią współpracę i mamy taką sytuację, że jest tam byłych działaczy „,Solidarności” dużo, na przykład jedna z koleżanek z Łodzi nie mogła się z Regionem Łódzkim dogadać i z Regionem Mazowsze, i musiała przejść do Forum Związków Zawodowych, bo „Solidarność" nie potrafiła tego problemu organizacyjnego między dwoma organizacjami rozwiązać. Ten problem ostatecznie się rozwiązał sam poprzez to, że ten akurat związek zawodowy przystąpił do Forum Związków Zawodowych.

Chciałbym jednak jeszcze poruszyć chwileczkę jeden problem niesłychanie istotny. Być może mówiłby o tym Dominik, gdyby tu był, że jest niesłychanie ważną sprawą, żeby związki zawodowe były silne od strony prawnej, bo od drugiej strony mamy partnera, przeciwnika bardzo sprawnego, bo on ma całą strukturę urzędniczą, na przykład rektor, który ma iluś prawników, ma urzędników, którzy wertują przepisy itd. Jest więc niesłychanie ważne, by w centralach związkowych i również na tym poziomie regionalnym było wsparcie prawnicze, i to takie rzeczywiste. Ja mogę powiedzieć, że tutaj wspólnie działając przez wiele lat wielokrotnie zgłaszaliśmy problem, koleżanka Żurawska może potwierdzić, wielokrotnie zgłaszaliśmy problem, kwestię obsługi prawnej i właśnie Dominik był tym, który właśnie w lipcu 2011 roku, a więc niedługo po tym, jak został przewodniczącym naszego Regionu, zrozumiał, że właśnie ta obsługa prawna jest najważniejsza, że po prostu on może mówić o różnych rzeczach, ale wygranie jakiegoś procesu i pokazanie, że pracownicy, którzy są niesłychanie słabi i sami nie mają żadnych szans, to wygranie takiego procesu, to jest coś, to jest pokazanie siły związku zawodowego. Myśmy to przećwiczyli „na myszach”, czyli na sobie, mieliśmy taki konflikt na AWF, czyli na Akademii Wychowania Fizycznego w Katowicach. Rek-

242 tor tam zlikwidował Studium Języków Obcych i zwolnił około 20 pracowników 
z tego studium za jednym machnięciem ręki, oczywiście, robił wcześniej jakieś podchody w senacie, tak że obudował to od strony prawnej. Jednak dzięki temu, że w Regionie było wsparcie, koleżanki, bo w większości to były koleżanki — te osoby pokrzywdzone w tym Studium Języków Obcych - to wygrały, ten proces w pierwszej instancji, i to większość z nich wygrała, i dostały jakieś odszkodowania finansowe. Te, które kontynuowały proces, wygrały w sądzie okręgowym odwołanie od tego wyroku i zostały przywrócone do pracy, a po dwóch latach otrzymały również odszkodowania finansowe, i to takie za dwa lata pracy, to jest kilkadziesiąt tysięcy złotych. Nie wszystkie, oczywiście, wytrzymały tę presję, bo niektóre po prostu zrezygnowały na tym pierwszym etapie i już się dalej nie odwoływały, zadowoliły się tym, że dostały jakieś tam odszkodowania za kilka miesięcy pozbawienia pracy itd. Zwracam więc uwagę, że związki zawodowe mają taki bardzo poważny problem, żeby zbudować sobie struktury prawne, które nam się udało zbudować, i mam nadzieję, że to, co mówię, to będzie też działało również w przyszłości. Ta obsługa jest na przyzwoitym poziomie. Mecenas, który dostał to zadanie w 2011 roku, dostał ode mnie ileś tam ustaw i projektów rozporządzeń, różnych aktów prawnych i jak się przez to przegryzł, to dzisiaj jest jednym z najlepszych prawników z zakresu prawa pracy w tym obszarze — nauka i szkolnictwo wyższe.

Wracając do układów zbiorowych pracy dla nauki szkolnictwa wyższego. To kiedyś było zapisane, że jest taka możliwość, że układ zbiorowy w szkolnictwie wyższym może być zawarty, ale sygnałem ostrzegawczym ostatnio stało się coś takiego, co słyszałem i widziałem na własne oczy, mianowicie szef wszystkich rektorów, czyli capo di tutti capi, a więc szef KRASP-u Pan Rektor Politechniki Warszawskiej oświadczył na jednej z konferencji poprzedzających Narodowy Kongres Nauki, że gdyby nie to, że jest taka obudowa prawna, to zwolniłby od 20 do $30 \%$ pracowników. To powiedział oficjalnie na forum ogólnokrajowym. Wszyscy to słyszeli, jak nie słyszeli, to mogę wysłać link do tego nagrania, gdzie on to powiedział. Został wsparty przez największy polski uniwersytet, czyli Uniwersytet Warszawski, ustami jego byłej Pani Rektor. Tu się zapala więc bardzo silne ostrzegawcze światło, że trzeba tego dopilnować, żeby ten układ zbiorowy jednak został zwarty, niezależnie od tego, jak długo to będzie trwało. Ja wiem, że to jest problem, ale ten problem można załatwić. Przykładowo, ja wiem, że jeżeli rzeczywiście chcemy, by były kominy płacowe, to możemy to załatwić przez kontrakty na uczelniach za konkretną robotę i wtedy taki pracownik, który realizuje taki kontrakt może zarobić więcej, ale mamy czytelną sytuację. Ja wymieniałem małe kwoty, bo rzeczywiście na uczelniach się słabo zarabia. Nie wiem, czy może akurat tutaj są lepsze przykłady na sali, ale wydaje mi się, że w środowisku naukowym się słabo zarabia, ale zarabia się, jeśli ktoś ma grant, to okresowo przez dwa czy przez trzy lata może więcej zarobić. Natomiast wiem, że to nie przekracza możliwości intelektualnych, żeby zrobić dobry zbiorowy układ pracy, który będzie działał. Ja w 1989 roku nie miałem zielonego pojęcia o tym i zostałem wmontowany w przygotowanie układu zbiorowego w swoim Instytucie, to była wtedy jednostka badawczo-rozwojowa, i ten układ działa do dzisiaj, choć był tam, oczywiście, 
modyfikowany, bo zmieniały się przepisy itd. To jednak pokazuje, że można było zbudować w epoce, że tak powiem przedkomputerowej, bo wtedy na komputer, to się zapisywało i dostawało się dwie godziny w tygodniu — można było zrobić układ zbiorowy pracy, do którego było na przykład w naszym przypadku 400 uwag $i$ te wszystkie uwagi w jakiś sposób zostały skonsumowane w układzie zbiorowym. Takie możliwości więc są i niech nikt nie mówi, że publiczne szkoły wyższe w Polsce są jakimś ewenementem, gdzie nie jest to możliwe. Dziękuję.

\section{Aneta Trojanowska:}

Proszę Państwa, widzę, że mamy już przekroczony czas, więc nie chcę się tu długo wypowiadać. Generalnie przyłączam się do głosów wcześniejszych, zwłaszcza tych dotyczących ekspertów, których musimy mieć jako istotne wsparcie działalności związkowej. Teraz, na moment proszę zapomnieć, że jesteśmy na uczelni wyższej i w takim towarzystwie, bo to nie do końca jest nasz problem. Wydaje mi się, że taka sieć musi być zbudowana właśnie przez te organizacje, które nie działają na uczelniach wyższych, które nie mają dostępu do naszych ekspertów. Jeżeli jako związki zawodowe i naukowcy stworzymy sobie wewnętrzną sieć związkową, to wtedy możemy nawzajem się wspomagać i służyć pomocą. Jak szukamy sojuszników, to przede wszystkim sami musimy wiedzieć, o co chodzi. Powinniśmy więc organizować różnego rodzaju konferencje, workshopy, warsztaty, jakkolwiek byśmy to nazwali. Korzyści ze spotykania się i wymieniania doświadczeń, także w kuluarach, są ważne.

Ale wsparcie świata nauki, jak najbardziej, bez tego sobie nie poradzimy. Jeśli brakuje tego wsparcia, to liderzy związkowi często są stawiani w sytuacjach, kiedy nie potrafią nawiązać dialogu ze swoim pracodawcą na równym poziomie. My, związkowcy, jako osoby negocjujące, czujemy się gorzej z racji tego, że mamy naprzeciwko siebie - no nie wiem - rektora, profesora, dyrektora. My, jako związkowcy, często będący zwykłymi szeregowymi pracownikami danego zakładu pracy, musimy stanąć naprzeciwko i przedstawić propozycje w imieniu naszych członków, a to nie jest łatwe. Środowisko akademickie może z pewnością wspierać świat związkowy i chciałabym, żeby tak było. Widzę, także w tym obszarze, ogromną rolę socjologii, bo, powiem szczerze, że niewiele o tej nauce do tej pory wiedziałam. Przebywając tu, w Waszym gronie, teraz wiem więcej i widzę, że jest to taka nauka, która bardzo może nas mocno wesprzeć. Słowem, twórzmy sieci wewnętrzne, zewnętrzne między sobą, ale też wprowadźmy, co też tu padało w wypowiedziach, wiedzę dotyczącą związków zawodowych do szkół. Ja nie znam aktualnych programów szkolnych, może tu lepiej by się moje koleżanki nauczycielki wypowiedziały. Są chyba w szkołach takie przedmioty, w ramach których tą wiedzę można wprowadzać, kiedyś to była propedeutyka nauki o społeczeństwie czy wiedza o społeczeństwie. Tam powinny być przedstawione informacje i wiedza o związkach zawodowych. Wprowadzajmy także na uczelnie wyższe informacje dotyczące działalności związków zawodowych. My, razem z koleżanką Olą Rezler, Prezes Zarządu Okręgu Śląskiego ZNP, też 244 taką akcję podjęłyśmy. Chcemy, żeby studenci na kierunkach pedagogicznych 
dostawali informacje o możliwości działania w związkach zawodowych. Powinno się takie zajęcia prowadzić pod kątem młodej kadry nauczycielskiej, żeby młody nauczyciel w swojej szkole mógł się zgłosić do działającego związku i uzyskać fachową wiedzę, jak on ma sobie poradzić z zajęciami, z uczniami, z problemami, przed jakimi często staje. Niech przyjdzie do związków po rozwiązanie swoich problemów, ale trzeba mu tę ideę zaszczepić już na studiach. Powinien wiedzieć, że jest takie miejsce, w którym znajdzie wsparcie, ale także w którym on może być aktywny i kreować społeczeństwo obywatelskie. Wprowadzajmy tę wiedzę i współdziałajmy na wszelkich możliwych płaszczyznach, róbmy razem projekty naukowe, róbmy razem konferencje, rozmawiajmy. Myślę, że to da taki fajny efekt i przełoży się później na wzrost siły związków zawodowych. Dziękuję.

\section{Slawomir Wittkowicz:}

Co do tych ostatnich uwag Pani Anety Trojanowskiej, to z pewnością zgoda, bo ważne są kontakty społeczne, wiedza, gdzie mamy szukać tych sojuszników. Powiem tak, z mojego punktu widzenia sojusznikiem będzie każdy, kto chce coś zmienić, kto będzie działać na rzecz dobra społecznego, to już jest potencjalny argument, aby nawiązać współpracę, aby poszukać wspólnych elementów. Ja nie twierdzę, że będzie to na zasadzie „kochajmy się”, że każda osoba, która zgłosi się z jakimś pomysłem, uzyska zawsze wsparcie, bo jednak głównym naszym zadaniem jest reprezentowanie interesów konkretnych grup pracowniczych. Nasz punkt widzenia jest z tym związany, z tymi priorytetami. Mamy też świadomość tego, że bez kontaktu z fachowcami, którzy mają krytyczne spojrzenie, ale mają też kontakty, wiedzę, doświadczenie, chociażby jak zorganizować to sieciowanie, to już jest wartość, którą warto wykorzystać. W środowisku młodych pracowników naukowych, tak, pojawiają się już różne inicjatywy, w zakresie tego, czego im brakuje. Taki przykład, to w kuluarach z Panią Profesor rozmawialiśmy, na Uniwersytecie Warszawskim Komitet Kryzysowy Humanistyki Polskiej zorganizował projekt wskazujący na konieczność wyposażania studentów w podstawową, elementarną wiedzę o prawach pracowniczych itd. To jest moim zdaniem też kierunek, tylko dzisiaj to jest incydentalne, choć wykorzystano środki unijne do tego akurat szczytnego celu, za co chwała i trzymam kciuki, żeby to już pewne efekty dało. Na dwóch kluczowych z naszego punktu widzenia ministerstwach, a więc na ministrze edukacji narodowej oraz na ministrze nauki i szkolnictwa wyższego trzeba wymóc, po prostu, takie prawne przymusowe odpowiednie zapisy, bo to jest ważne, aby ułatwiać te zbiorowe układy pracy. To jest punkt startu.

To, że związki zawodowe potrafią ze sobą współpracować mimo wszelkich różnic, także ambicjonalnych, osobowych, pewnej specyfiki własnej perspektywy, to zostawiamy tu te wszystkie elementy, bo mamy na to współdziałanie konkretne dowody, na przykład w oświacie, to był strajk w 2008 roku zorganizowany przez wszystkie związki zawodowe działające w sektorze oświaty z dużą premią otrzymaną od niezrzeszonych. To po raz pierwszy od 1989 roku zmusiło ówczesny rząd do podjęcia oficjalnych rokowań i podpisania porozumienia kilkumiesięcznego, które skutkowało może nie wszystkim, co chcieliśmy, ale pokazało, że wspólny 
nacisk może być efektywny. Kwestia, którą Pan Profesor poruszył, pomijania Rady Dialogu Społecznego, to jest bardzo ważny przykład, ale ja podam drugi minister rolnictwa i rozwoju wsi Krzysztof Jurgiel nie tak dawno powołał Radę Dialogu Społecznego w Rolnictwie, czyli odrębną instytucję, gdzie powołał tam, tak to określę, zaprzyjaźnione firmy i organizacje, a w ten sposób on już opinię pozytywną ma do swoich pomysłów. Jeśli chodzi o kwestię głośną, bardzo aktywną i taką ważną społecznie, ten protest lekarzy rezydentów, to on wrócił na forum Rady Dialogu Społecznego właśnie dlatego, że trzy centrale reprezentatywne oraz organizacje pracodawców stwierdziły, że jeśli to nie będzie rozgrywane w RDS-ie, to one w zespole Radziwiłła funkcjonować też nie będą i to przymusiło drugą stronę. Słowem, te wspólne działania w takich najbardziej elementarnych kwestiach są punktem startu, który może przynosić efekty, tak że myślę, że to jest właściwy kierunek. Dziękuję.

\section{Slawomira Kamińska-Berezowska:}

Proszę Państwa, aby nie przedłużać aktualnego spotkania, powiem teraz tylko tyle, że w moim odczuciu wniosek z dzisiejszej debaty jest taki, że można mówić o społecznej odpowiedzialności nauki oraz, podobnie, o społecznej odpowiedzialności związków zawodowych. Można starać się o lepszą współpracę między światem nauki a światem pracy i aktywności związkowej. Myślę, że ta integracja jest możliwa, że generalnie widzimy jej potrzebę. Problem jest „drobny”, jak to czynić w praktyce, ale podróż na tysiąc mil zaczyna się od pierwszego kroku, kroków, a zatem — jak rozumiem — będziemy starali się je stawiać, będziemy tworzyć więcej sieci współpracy, a także troszczyć się o wypracowanie płaszczyzn sprawstwa dla tworzenia, wspierania przyjaznej dla świata pracy społecznej gospodarki rynkowej. 